\begin{tabular}{|c|c|c|}
\hline e-ISSN 2458-9519 & $\begin{array}{c}\text { Osmanlı Medeniyeti Araştırmaları Dergisi } \\
\text { Journal of Ottoman Civilization Studies } \\
\text { Cilt 5, Sayı 8, Nisan } 2019 \text { \& Vol 5, No 8, April } 2019 \\
\text { C2018 Telif Hakkı OSMED'e aittir }\end{array}$ & atring \\
\hline DOI: 10.21021/osmed.551075 & Makale Türü: Araştırma Makalesi & Article Types: Research Article \\
\hline Geliş Tarihi \& Received: 02.03.2019 & Kabul Tarihi \& Accepted: 04.04.2019 & OSMED, 2019, 5(8): 93-114 \\
\hline
\end{tabular}

\title{
Bir Uzun Hikâye: Cihangir Camii İnşaatı
}

\author{
A Long Story: The Construction of Cihangir Mosque
}

\section{Osman Taşkın*}

\section{$\ddot{O} z$}

Bu makale Kanuni Sultan Süleyman'ın oğlu Şehzade Cihangir adına boğaza hâkim bir tepede yaptırdığı Cihangir Camisi'nin sürüncemede kalan yeniden yapılışına odaklanmışıı. Çalışmada öncelikle caminin gördüğü onarımlar ve nihayetinde Sultan Abdülaziz'in 1873 yılında başlatıp II. Abdülhamid'in 1890 yılında tamamlatmasına kadar geçen 15 yıl 7 aylık yeniden inşa süreci ele alınmıştır. Aynı zamanda küçük bir cami inşaatı çerçevesinde Osmanlı Devleti'nin iktisadi zorluklarına ve izlediği para politikası ile bürokrasinin hantallı̆̆ına dair izlenimlere ulaşmak mümkün olmuştur. Sonuç olarak cami batılılaşma sürecinin okunabildiği bir mimari değişime uğramışsa da XVI. yüzyılın temel mimari yapısını da muhafaza etmiştir.

Anahtar Kelimeler: Cihangir Camisi, Mimari, Modernleşme, Cami İnşaatı.

\begin{abstract}
This article consists on the long-standing reconstruction of the Cihangir mosque built on a hill that overlooking the Bosporus in the name of the son of the magnificent Sultan Suleiman, Şehzade Cihangir. In this study, primarily the repairs that the mosque underwent and eventually the 15-year 7-month reconstruction period from 1873 when Sultan Abdülaziz started to 1890 when Abdülhamid II. had it completed was discussed. Meanwhile, within the framework of a small mosque construction, it is possible to reach the economic difficulties of the Ottoman Empire and its monetary policy and the awkwordness of bureaucracy. As a result, the mosque underwent an architectural change in which the westernization process could be seen, but it also retained the basic architectural structure of the 16th century.
\end{abstract}

Keywords: Cihangir Mosque, Architecture, Modernization, Construction of the Mosque.

*(Dr.); Milli Eğitim Bakanlığı, osmtsk@gmail.com; ORCID: orcid.org/0000-0002-6193-7169

Kaynak Gösterme: Taşkın, O. " Bir Uzun Hikâye: Cihangir Camii İnşaatı". Osmanlı Medeniyeti Araştırmaları Dergisi 5 (2019): 93-114. 


\section{Giriş}

Devleti Aliye'nin en uzun hükümdarlığını yapan Kanuni Sultan Süleyman'ın gerek hayatı gerekse eserleri birçok yerli ve yabancı bilim insanı tarafından incelenmiştir. Onun muharebeleri kadar kurmuş olduğu ilmi ve hukuki müesseselerin de önemli olduğuna yapılmıştır. ${ }^{1}$ Hükümdarın düşmanlarına korku veren dış görünüşüne ve sert ${ }^{2}$ tabiatına karşın hisli dünyasının geçirmiş olduğu sarsıntıların birer nişanesi olan eserleri günümüze kadar gelmiştir. Mihrimah adında bir kızı ve beş oğlu olmuştur. ${ }^{3}$ Sultan'ın yaşadığı en büyük sarsıntılardan birisi Şehzade Mehmed'in ölümü olmuş ve onda büyük izler bırakmıştır. Onu çok sevdiği ve kendisinden sonra tahta onun oturmasını istediği söylenir. Ne var ki şehzadenin Manisa'ya tayin edilmesinden bir süre sonra 1543 'te zamansız ölümü Sultanı çok üzmüştür. ${ }^{4}$ İç dünyasında oğlunu yaşattığını gösteren en önemli emare adına yaptırdığı Şehzade Camisi’yle somutlaşmıştır. Sultanının bir diğer derdi hasta oğlu Cihangir idi. Mehmed'in küçük kardeşi olan Cihangir'i hastalığı sebebiyle sancağa çıarmamış sürekli yanında tutmuştur. ${ }^{5}$ Peçevi tarihine göre 923 (1526/27) doğumlu olan Cihangir padişahın gözünün nuru ve sevinç kaynağı olmuştur. Savaşta ve barışta padişah onu hiç yanından ayırmamıştır. Ancak çok hisli bir yapıya sahip olduğundan büyük kardeşi Şehzade Mustafa hadisesinden çok etkilenmiş Halep kışlağında vefat etmiştir. ${ }^{6}$ Cenazesi İstanbul'a nakledilerek Şehzâde Cami bahçesinde abisinin türbesine defnedilmiştir. ${ }^{7}$ Kanuni Sultan Süleyman daha sonra Topkapı Sarayı'ndan görünen bir yerde Cihangir'in çok sevdiği ve zaman zaman gelerek seyre daldığı söylenen Tophane sırtlarında 1559-1560 yıllarında onun adını yaşatacak bir cami yaptırmış ve kurmuş olduğu vakfa dahil etmiştir. ${ }^{8}$ Caminin arşiv kayıtlarında resmi adı "Cennetmekân Sultan Süleyman Hân tâbe serâh hazretleri hayrât-ı celîlelerinden Tophane-i Amire'de kâin Cihangîr Cami-i Şerifi" dir. ${ }^{9}$ Evliya Çelebi caminin yerinde bir

\footnotetext{
${ }^{1}$ Yasin Yılmaz, Kanûnî Vakfiyesi Süleymaniye Külliyesi, (Ankara: Vakıflar Genel Müdürlüğü, 2008), 22.

${ }^{2}$ Ogier Ghiselin De Busbecq, Türk Mektupları, çev., Hatice Özkan, (İstanbul: Ark Kitaplar,2018), 135. Busbecq burada 1560 yılında İstanbul'da kaldığı süreçte gördüğü Sultanı: "Yüzünün ifadesi sertti. Kaşları çatıktı. Öfkeli olduğu gayet açıktı" şeklinde tarif eder. Ayrıca aynı eser 211. sayfada: "Süleyman hem kendisinin hem de atalarının başarılarının uyandırdığı dehşetle karşımızda duruyur" der.

${ }^{3}$ Sedat Çetintaş, Istanbul ve Mimari Yazıları, (Ankara: Türk Tarih Kurumu (TTK), 2011), 116.

${ }^{4}$ Şerafettin Turan, Kanunînin Oğlu Şehzade Bayezid Vakâsı, (Ankara: TTK, 1961), 20

${ }^{5}$ Turan, Bayezid Vakâsı, 19.

6 Ibrahim Peçevi, Peçevi Tarihi 1059/1649, haz., Bekir Sıtkı Baykal, 1. cilt., (Ankara: Kültür Bakanlığı, 1981), 15; Ayvansarâyi Hüseyin Efendi, 1201/1787, Ali Sâtı' Efendi, Süleymân Besim Efendi, Hadikatü'l- Cevami, (İstanbul camileri ve diğer dini-sivil mimari yapılar) haz. Ahmed Nezih Galitekin. (istanbul: İ̧̧aret Yayınları, 2001), 473.

${ }^{7}$ Turan, Bayezid Vakâsı, 37; İsmail Hakkı Uzunçarşılı, Osmanlı Tarihi, 2. cilt. (Ankara: TTK, 1961), 404; İbrahim Peçevi, Peçevi Tarihi, 15, Eremya Çelebi Kömürciyan, İstanbul Tarihi XVIII. Asırda Istanbul, (istanbul: Eren Yayınları, 1988), 39 (Kömürciyan Şehzade Cihangir'in Cihangir Cami'si haziresine gömüldüğü hususunda yanılmışır); Evliya Çelebi Seyahatnamesi Topkapı Sarayı Bağdat 304 Yazmasının Transkripsiyonu-Dizini., haz. Orhan Şaik Gökyay 1. Kitap, (İstanbul: Yapı Kredi Yayınları, 1996), 67.

8 Süleymaniye Vakfiyesi, Mukaddimeyi ve Metni Hazırlayan: Kemal Edip Kürkçüoğlu, (Ankara: Vakıflar Umum Müdürlüğü, 1962), 182-183; Ayvansarâyi Hüseyin Efendi, Hadikatü'l-Câvâmi, 473; Evliya Çelebi, Seyahatname, 68; Ressam Hüsni, Bedâyi'-i Âsâr-ı Osmâniye, (İstanbul: Matbaa-i Harbiyye, 1335), 46; Ebru Türker, Cihangir Camisi Mimarlık Tarihi, Basılmamış Yüksek Lisans Tezi, (İstanbul: İstanbul Teknik Üniversitesi, 2015), 15.

${ }^{9}$ VGMA, Defter 1809/37.
} 
manastırın olduğunu ve onun yerine bina edildiğini söyler. Caminin bulunduğu semtin adı ise Fatih Sultan Mehmed'in inşa edip II. Bayezid'in de genişlettiği Tophane'den gelmiştir. ${ }^{10}$

Cihangir Camisi'nin klasik dönem camilerine benzer dikdörtgen planlı ve tek minareli olduğu bilgisi dışında pek bir iz kalmamıştır. 1590'lara ait bir tabloda ince uzun bir minaresi ve kare planlı küçük bir cami olduğu açıkça görülmektedir. ${ }^{11}$

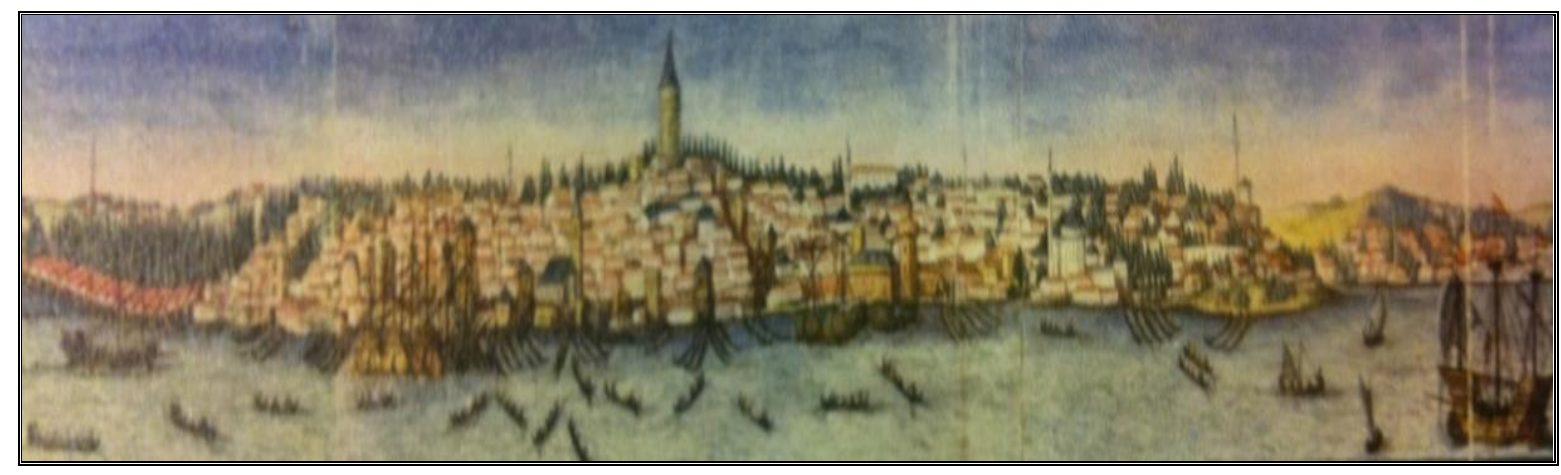

Resim 1: 1590 tarihli Boğaziçi'nin suluboya panoramik resmi sağda tepede Cihangir Camisi (Gülrü Necipoğlu, Sinan Çağı, 141)

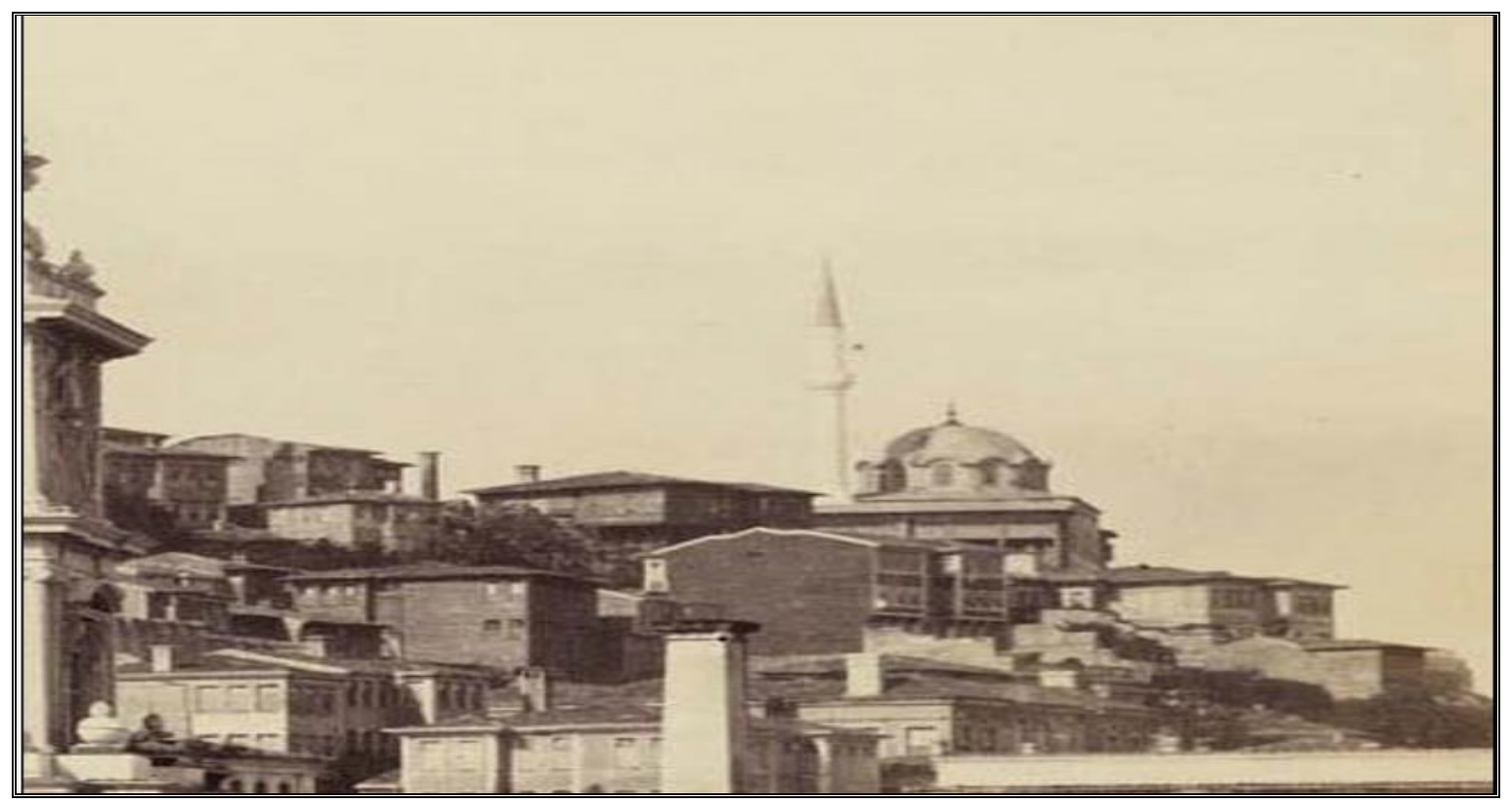

Resim 2: James Robertson \& Felice Beato Fotoğrafında Cihangir Camisi 1854-56, Pera Müzesi Arşivi (Türker, Mimarlık Tarihi, 59)

10 Evliya Çelebi, Seyahatname, 185.

11 Şekil 1 
1823 Tophane yangınında yanmasına kadar bu şeklini korumuştur. Yeniden yapılan caminin devrin mimari özelliklerini taşıyan bir karakterde; kubbe, kasnak, pencere düzeni ve minaresi bakımından 1826 'da yapımı bitirilen Nusretiye Camisi ile benzerlikler taşımaktadır. ${ }^{12} 1865$ tarihli bir başka fotoğrafta yine tek minareli, yüksek kasnakl, pencereli ve dalgalı saçaklı bir kubbe yapısıyla aynı şeklini korumuştur. ${ }^{13}$

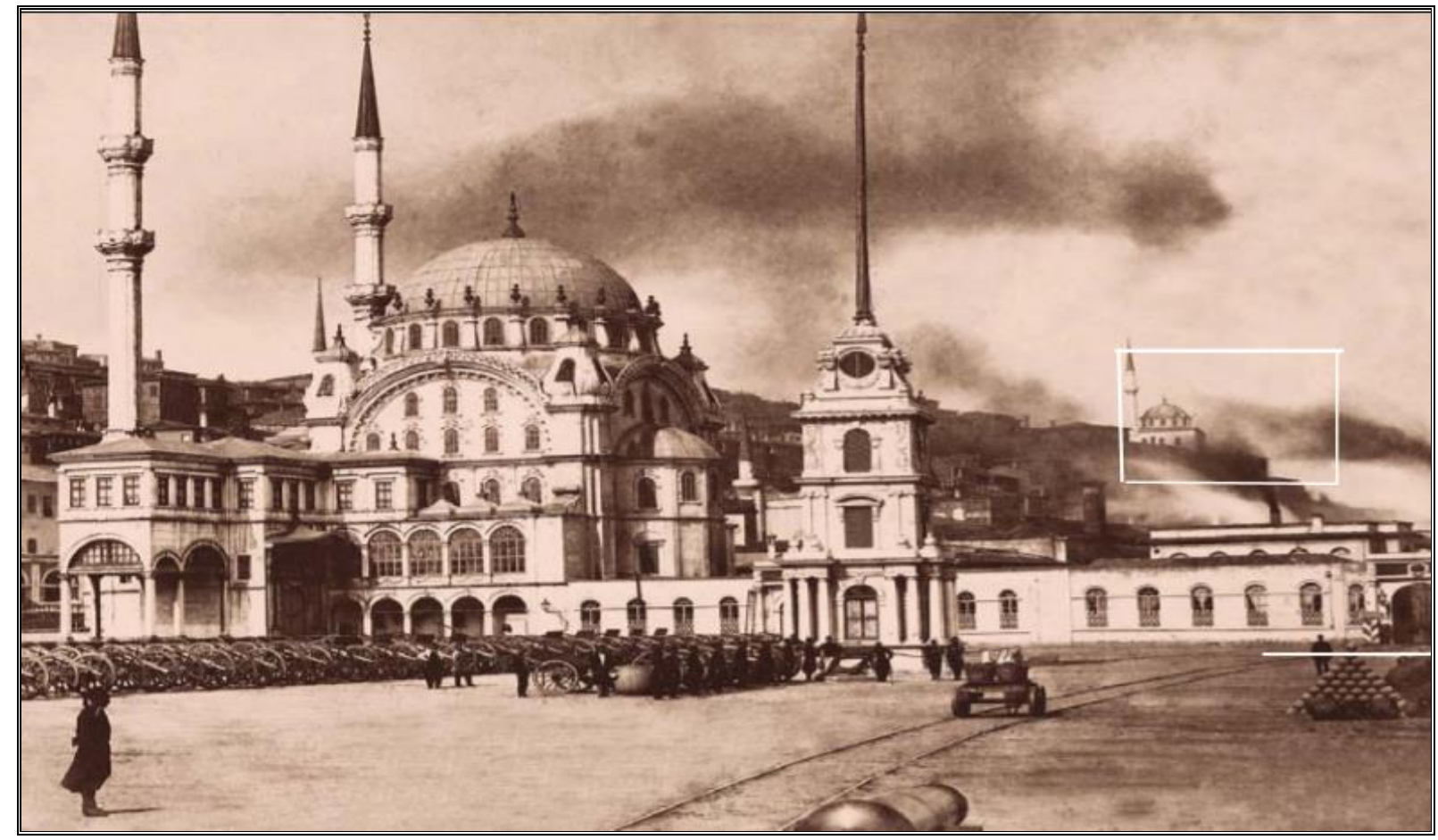

Resim 3: Pascal Sebah'ın 1865 yılında çektiği Nusretiye Camisi Fotoğrafinda Cihangir Camisi, İstanbul Araştırmaları Enstitüsü (Türker, Mimarlık Tarihi, 64)

1873 yılında çıkan bir yangından önceki son hali güney cephesinden görülen bir fotoğrafta iki katlı, üst katta kubbe kasnağında ve alt katta beşli pencere sistemine ek olarak istinat duvarı net bir şekilde seçilmektedir. ${ }^{14}$ Bundan sonra yapılan ve günümüze kadar gelen son şeklini ise bir uzun hikâyeye dönüşen Eylül 1873-Nisan 1890 yıllarını kapsayan bir süreçte almıştır. Ayrıca bir kısmına kadar yapılı olan ikinci minaresi de 1970'lerde eklenmiştir. ${ }^{15}$

\footnotetext{
12 Türker, Mimarlık Tarihi, 58, 61; Şefaattin Deniz, "Sultan II. Mahmud’a Ait İki Vakıf Eser: Arabacılar Kışlası ve Nusretiye Camileri, Türk Dünyası Araştırmaları, 218, Ekim (2015): 167; Şekil 2.

13 Şekil 3

14 Şekil 4.

15 Şekil 6.
} 


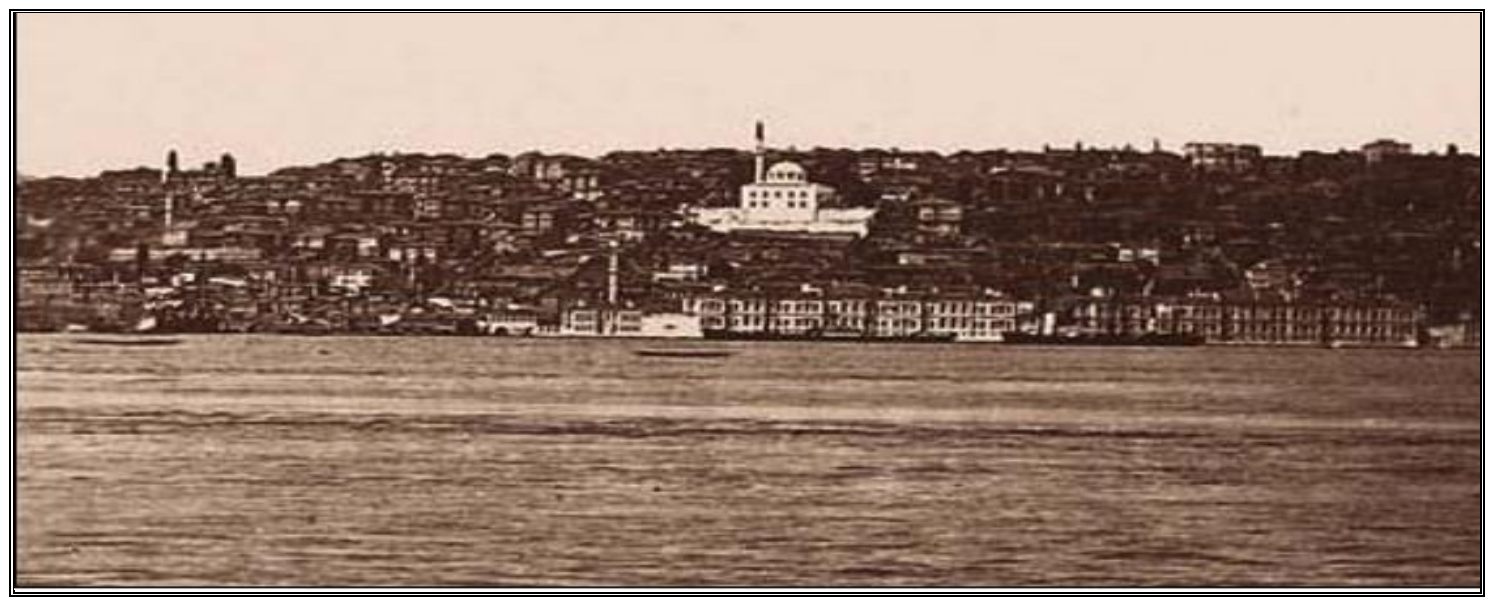

Resim 4: Pascal Sebah'ın çektiği Kızkulesi fotoğrafında görünen Cihangir Camisi, 1870, İstanbul Araştırmaları Enstitüsü (Türker, Mimarlık Tarihi, 66)

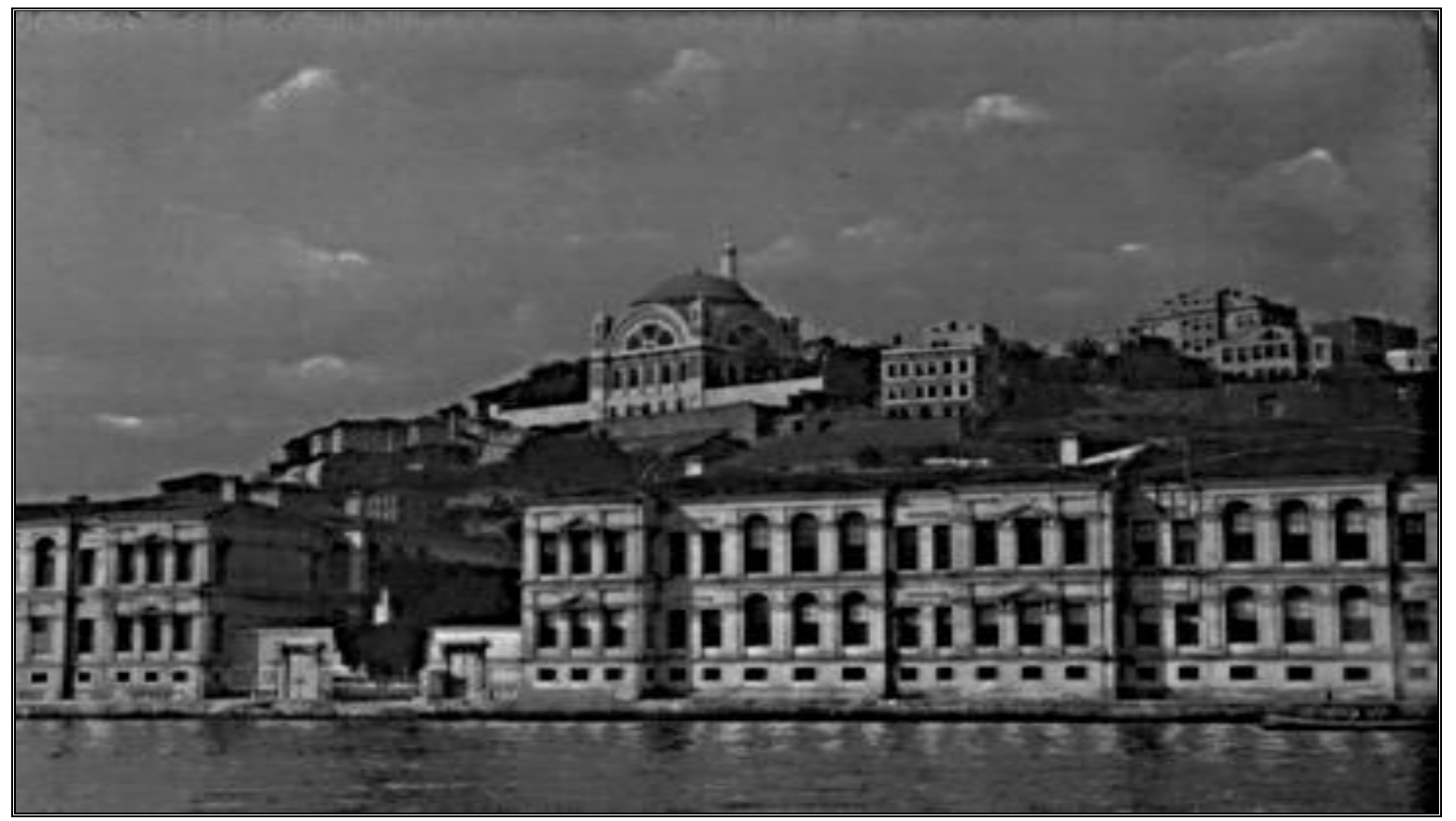

Resim 5: II. Abdülhamid Albümü'nde Cihangir Camisi, Abdullah Freres fotoğrafı, 1890-93 (Türker, Mimarlık Tarihi, 71) 


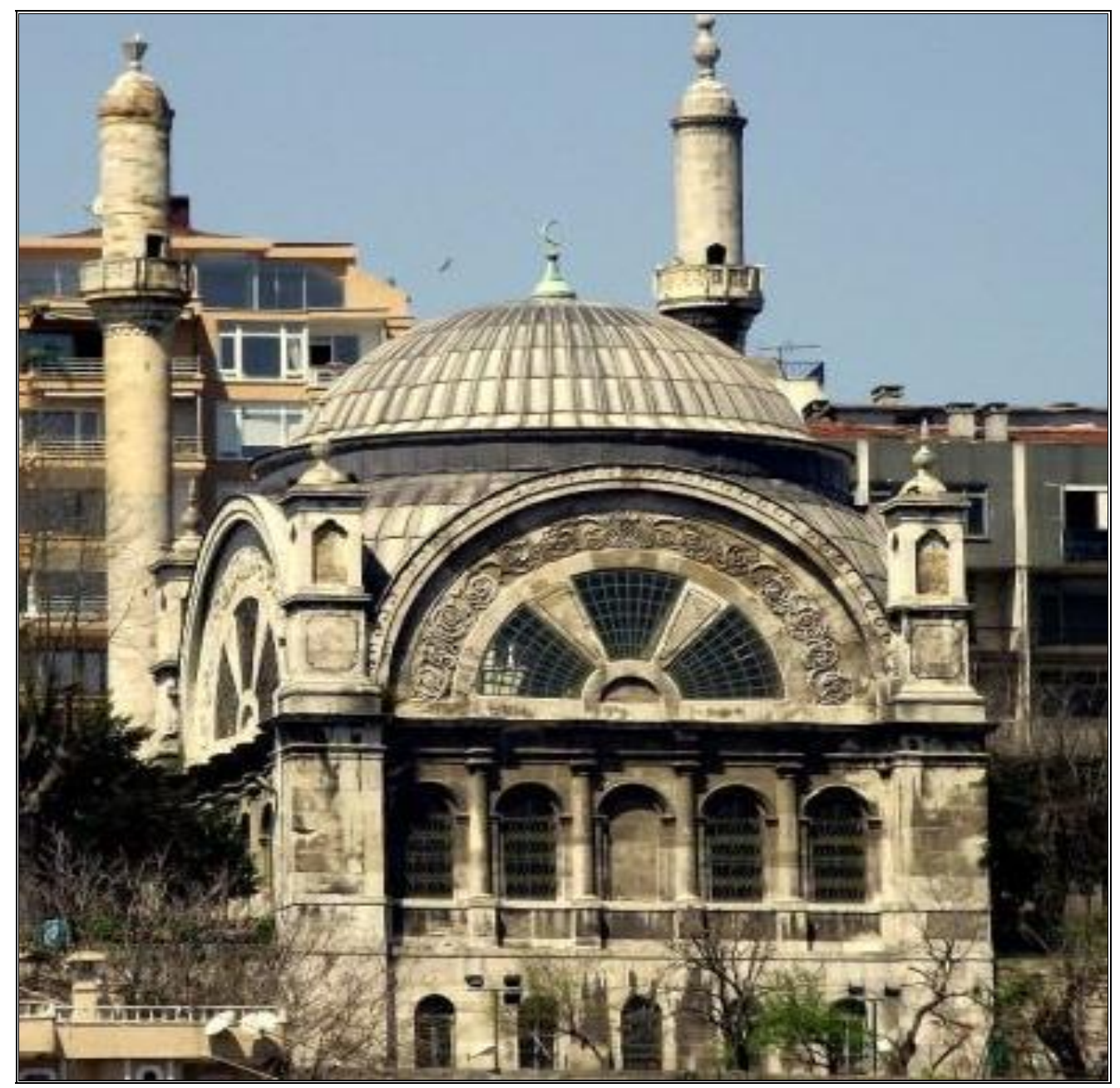

Resim 6: Cihangir Camisi

\section{Caminin mimarı ve mimarisi}

Caminin yeniden yapılış sürecine geçmeden önce bugünkü şeklini veren mimarının kim olduğunu yeni belgeler işığında yeniden değerlendirerek netleştirmek ya da teyit etmek yerinde olacaktır. Haluk Sezgin'in Sarkis Balyan ${ }^{16}$ olduğunu söylemesine karşın Ara Altun, balyan ailesine ait eserler arasında gösterilmemiş olmasından dolayı tereddütle karşılanması gerektiğini ifade etmiştir. ${ }^{17}$ Yeni bir arşiv kaydına göre cami ikmal inşaatının Sarkis Beg (Balyan) nezaretinde yapıldığı kesindir. 21.09.1873/28 Receb 1290 tarihinde inşaat emrinin verilmesiyle

\footnotetext{
${ }^{16}$ Balyan ailesinden Karabet Balyan'ın oğludur. Bkz. Şefaattin Deniz, Çırağan/Küçük Mecidiye Camii ve 2012-2015 Restorasyon Çalışmaları, (İstanbul: Vakıflar Genel Müdürlüğü Yayınları -126/ Oksijen Matbaacılık, 2017), 55.

17 Diyanet İslam Ansiklopedisi, Ara Altun, (İstanbul: İslam Araştırmaları Merkezi, 1993), 7. cilt., "Cihangir Camii" maddesi, 539; Haluk Sezgin, Türk İslam Ülkeleri Mimarisine Toplu Bakış, (İstanbul: Mimar Sinan Üniversitesi Yayınları, 1979), 204.
} 
cami inşaatının Üsküdarlı Heci Yani Kalfaya verilmesinden sonra inşaat çeşitli sebeplerden ötürü durmuştur. Ancak inşaatın tamamlanmasının önemine binaen takrar yapılmasına ve cami ikmal inşaatının "ser-mimar-ı devlet atûfetlü Sarkis Beg Efendi hazretlerinin nezâreti tahtında..." tamamlanacağı belirtilmiştir. ${ }^{18}$ İnşaatın başlangıcından beri Sarkis Beg'in nezaretinde olup olmadığına dair bir bilgi yoksa da 1872'lerde önemli bir kariyere sahip olduğu ve 1878 yılında devlet baş mimarı unvanını aldığı bilinmektedir. ${ }^{19}$ Sarkis Balyan’nın devlet baş mimarı olması münasebetiyle cami inşaatının asıl bölümlerinin onun nezaretinde yapılmış olması mimarının Sarkis Balyan olduğunu göstermektedir.

Semavi Eyice caminin beş kez yandıktan sonra her seferinde yeniden yapılmasından dolayı ilk şeklini kaybetmiş olduğunu ifade etmiştir. Ne var ki Mimar Sinan Şehzade Camisi'nde olduğu gibi Cihangir Camisi'nde de kare mekân üzerine kubbe, ek olarak yarım kubbeler ve köşelerde birer küçük kubbe kullanmıştır. Hatta Sinan'ın ilk eserlerinden olan bu yapıda tek kubbeli ve yanlarda ek birimleriyle süslemesiz ferah bir mekân tasarımı yeniden inşasında da devam ettirilmiştir. ${ }^{20}$ Elde edilen bilgiler caminin hep tek minareli ve kare planlı bir şekilde yapıldığını göstermektedir. Günümüzdeki cami dört kemer üzerine oturan tek kubbe, köşelerden iki katlı barok kulelerle desteklenmiştir. ${ }^{21}$ Mimar Sinan’ın Mihrimâh Sultan Cami’nde başlattığı mimari tasarım ve strüktür bu yapıda yeniden uygulanmıştır. Burada duvarlar taşıyıcı bir fonksiyon icra etmediğinden çok sayıda pencere açılabilmiştir. Aynı zamanda üst kısımlarda yelpaze biçiminde yayılan bir pencere düzeni gerçekleştirilebilmiştir. ${ }^{22}$ Günümüzde üç bölümlü son cemaat yerinin her iki yanında zarif iki minaresi vardır. Son cemaat yerinin tavan seviyesine kadar yapılıp yarım kalan kuzey batı köşesindeki minaresinin 1966 yılından sonra eklendiği anlaşılmaktadır. ${ }^{23}$ Yeni yapılan minare 1978 yılında yıkılarak 1981'de Vakıflar İdaresi tarafından orijinali örnek alınarak yeniden yapılmıştır. ${ }^{24}$

Cami planı ve süslemeleriyle oldukça ölçülü bir yapıda, gösterişten uzak bir tasarım sadeliğine sahiptir. Cephe süslemelerinde XIX. yüzyıl batılılaşma devri özelliklerini önemli ölçüde yansitmakta olup barok, rokoko, neoklasik, ampir süslemeler kendini göstermektedir. Cami içinde aydınlatma unsuru olarak avize, kandil kullanılmıştır. Cami içindeki kalem işi süslemeler iç mekâna ayrı bir özellik kazandırmıştır. Sonuç olarak Cihangir Camisi klasik

\footnotetext{
18 BOA.EV.MKT. 906/268.

19 Türker, Mimarlık Tarihi, s. 17; Altun, "Cihangir Camii", 539.

20 Semavi Eyice, Istanbul Minareleri I, (İstanbul: Berksoy Matbaası, 1962), 46; Türker, Mimarlık Tarihi, 15-17, 189.

${ }^{21}$ Oktay Aslanapa, Osmanlı Devri Mimarisi, (İstanbul: İnkılap Kitapevi, 1986), 465.

22 Altun, "Cihangir Camii", 539.

${ }^{23}$ Türker, Mimarlık Tarihi, 80'de Semavi Eyice'nin bu minarenin yapım yılını İstanbul Minareleri adlı kitabının 62. Sayfasında 1971 yılı olarak verdiğini ifade etse de bu bilgiyle karşılaşmadık. Eyice'nin Cihangir Camii Minaresi (1890) başlıklı yazısında: "Bina aslında çifte minareli olarak düşünülmüş ise de diğer minare ancak gövdesinin küçük bir parçasına kadar inşa edilebilmiştir" demektedir. Bkz. Eyice, İstanbul Minareleri I, 46. Ayrıca s. 92'de Resim 130131 'de Cihangir Camisi'nin tek minareli olduğu görülür.

${ }^{24}$ Türker, Mimarlık Tarihi, 138; Eyice, İstanbul Minareleri I, 62.
} 
Osmanlı cami planından sapma göstermeden dönemin üslubunu yansıtan tasarım ve süsleme özellikleriyle batı mimarlı̆̆ izlerini taşıyan bir yapıya sahiptir. ${ }^{25}$

Diğer yandan arşiv kayıtlarının teyit ettiği gibi selâtin camilerinde olduğu gibi cami içinde bir mahfil-i hümâyûn da yapılmıştır. Ayvansarâyi caminin mahfil-i hümâyûnu ve sıbyan mektebi ile avlusunun bir tarafında zaviye olduğundan bahseder. ${ }^{26}$ Cami avlusunda zaviye şeyhi olup 1663 'te vefat eden Hasan Burhaneddin Cihangîrî türbesi yer almaktadır. ${ }^{27}$ Halvetiye tarikatının Cihangiriyye şubesinin kurucusu Hasan Burhâneddin Caihangîri zaviyesinin hazine kayıtları da bunu teyit etmektedir. ${ }^{28}$ Gazi Osman Paşa türbeyi tamir ettirip ${ }^{29}$ cami avlusunda bulunan kuyuya tulumba monte ettirmiş ve şadırvan yaptırmıştır. ${ }^{30} 1891$ yılında mahkeme-i teftişin onayından sonra ev yapılmıştır. ${ }^{31}$ Vakfiyede geçen ve cami yandığında zarar gören mektep de yeniden yapılmıştır. ${ }^{32}$ Cami imamına ait meşruta yangında tamamen yok olduğu için 1876 yılında 37.000 kuruşa yeniden yapılmıştır. ${ }^{33} 1708^{\prime}$ de yapılan su sarnıcı da cami inşaatı sırasında bazı odalarla birlikte yeniden inşa edilmiştir. ${ }^{34}$

\subsection{Caminin geçirmiş olduğu onarımlar}

Cihangir semtinin sokak dokusu XVIII. yüzyıla kadar hızlı bir gelişme göstermiştir. Bu dönemde yapılan yapıların büyük bir kısmının ahşap olması 1765 de çıkan yangında semtteki yapıların tamamına yakınının yanmasına neden olmuştur. ${ }^{35}$ Caminin bulunduğu mevki eşsiz bir boğaz manzarası sunarken camiyi rüzgâr ve firtınaların etkisine de açık bırakmıştır. Arşiv belgelerinde cami kurşunlarının fırtına ve yağmurdan yıprandığına dair birçok kayıt bunu teyit etmektedir. ${ }^{36}$ Ama asıl hasarı şiddetli yangınlar bırakmıştır. Şemdanizade tarihinde 13 Nisan 1770 yılında gece saat beşte gerçekleşen büyük Fındıklı yangını beş saat sürmüş ve Cihangir Cami ile sahil arasını yakıp yok edip boş arsaya çevirmiştir. ${ }^{37}$ Yangında zarar gören cami zaman kaybedilmeden tamir edilerek masrafları Süleymaniye Vakfı'ndan karşılanmıştır. ${ }^{38} 1$ Mart 1823 tarihinde Firûz Ağa Cami yanında çıkan bir yangın on saat sürmüş ve Cihangir Camisi’ni de

\footnotetext{
25 Türker, Mimarlık Tarihi, XV; Altun, "Cihangir Camii", 539.

${ }^{26}$ Ayvansarâyi Hüseyin Efendi, Hadikatü'l-Câvâmi, 473

27 Diyanet İslam Ansiklopedisi, Reşat Öngören, (İstanbul: İslam Araştırmaları Merkezi, 1997), 16. cilt. "Hasan Burhâneddin Cihangîrî” maddesi, 310-311.

28 BOA.EV.MKT.CHT. 830/52; VGMA, Defter 08/59; VGMA, Defter 438/34, 1756-1846 yılları arasında görev yapan şeyhlere ait berat kayıtlarının olduğu iki ayrı hazine defterine ulaşılmıştır. İlk yıllara ait deftere ulaşılamamıştır.

${ }^{29}$ BOA.EV.MKT. 1878/76

${ }^{30}$ Altun, "Cihangir Camisi", 540

31 BOA.EV.MKT.CHT. 830/52; BOA.PLK.p. 224

32 Süleymaniye Vakfiyesi, 6, 183-184; BOA.EV.MH.TiK. 30/66; EV.MH.TiK. 109/189; EV.MH.Tí. $73 / 291$

33 BOA.EV.MH 1805/70; BOA.EV.MH.TIK 29/213; BOA.EV.MH. 1805/74

34 BOA.EV.MKT.737/278; Altun, "Cihangir Camii", 539.

35 Türker, Mimari Tarihi, 57.

${ }^{36}$ BOA.EV.MH, 233/116; BOA.EV.MH, 689/72

37 Şem'dânî-zâde Fındıklılı Süleyman Efendi Tarihi, Müri't-tevârih II.B., haz. M. Münir Aktepe, (İstanbul: İstanbul Edebiyat Fakültesi Matbaası, 1980), 26.

38 BOA. C.EV.598/30177
} 
yakmıştır. Caminin yapımına bir ay içinde başlanmıştır. ${ }^{39} \mathrm{Bu}$ sırada Arabacılar Kışlası Camisi'nin yanmasından sonra II. Mahmud onun yerine Nusretiye Camisini yaptırmıştır. ${ }^{40}$

1831 yılında caminin kıble tarafına bir mazgal inşa edilmiş ve yıkılan duvarlara 2.607 kuruş harcanmıştır. $^{41} 1832$ yılında yine cami ve mektep için 1.745 kuruş, ${ }^{42}$ aynı yıl mahfil-i hümâyûn için 929 kuruş harcanmıştır. ${ }^{43} 1834$ yılında minare dibi ve mahfil-i hümâyûn ile merdiven üstü, abdest odası yanındaki odanın bir tarafının döküldüğü, yerlerdeki hasırların bir kısmının çürüdüğü, su yolunun bozuk olduğu ve suyun kesik olduğu ${ }^{44}$ anlaşılmaktadır. Su yolu ve cami içinde yapılan tamirat için toplam 3.985,5 kuruş masraf edilmiştir. ${ }^{45} 1837$ yılında cami tamiri için Evkaf-1 Hümâyûn hazinesinden 2.750 kuruş ödenmiştir. ${ }^{46}$ Aynı yıl temmuz ayında cami camları değişmiş ve yine aynı hazineden ödenmiştir. ${ }^{47}$

1842 yılı Mayıs ve Haziran ayında yapılan çeşitli tamiratlar için toplam 3.794 kuruş harcama yapılmıştır. $^{48} 1843$ nisan ayında su yolu için 7.986 kuruş, su hazinesinin tamiri için de 1.171 kuruş keşif bedeli çıkarılmıştır. ${ }^{49}$ Sadece Sormagir sokağından su hazinesine kadar gelen boruların ve künklerin değişmesi için 7.947 kuruş ödenmiştir. ${ }^{50}$ Yine aynı yıl cami mahfilinin düşmesi sonucu bazı dolap ve saire için 330 kuruş, cami kurşunları, su yolu ile çeşme ve mektep için toplam 1.610,5 kuruş harcama yapılmıştır. ${ }^{51} 1849$ yılında ise çıkan firtınalar cami üzerinde hasara neden olmuş hasarın gideri Evkaf-1 Hümâyûn hazinesinden karşılanmıştır. ${ }^{52}$

1857 yılında hazırlanan keşif defterine göre yapılan münakasa ${ }^{53}$ ile 23.750 kuruşluk bir tamir gerçekleştirilmiştir. ${ }^{54} \mathrm{Bu}$ miktar önemli bir tamiratın gerçekleştirildiğini göstermektedir. Zira bu dönemde yapılmış olan Teşvikiye Camisi 317.989 kuruşa mal olduğu düşünüldüğünde tamiratın

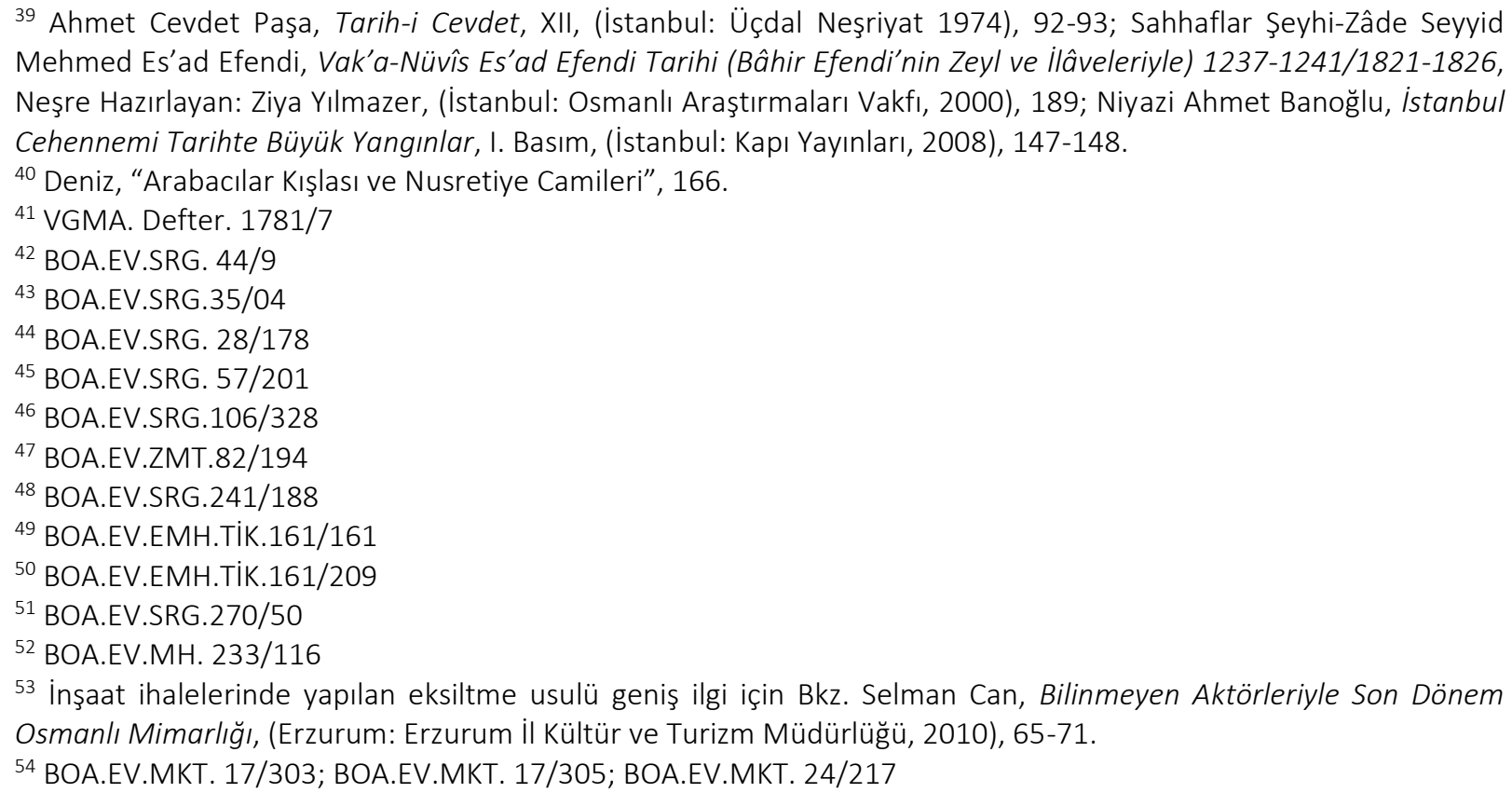


küçük onarım olmadığı söylenebilir. ${ }^{55} 1858$ Eylül ayında yine şiddetli rüzgârdan cami üzerindeki kurşunlar zarar görümüş bunun için 1.991 kuruş harcanmıştır. ${ }^{56}$

1862 y1lı sonlarında 27.000 kuruş gibi bir masraf gerçekleşmiştir. Şubat ayında çıkan Tophane yangınından etkilenmiş olmalıdır. ${ }^{57} \mathrm{Bu}$ tamiratta yüklenici olan Heci Yani Kalfanın 1873 yılında caminin yeniden yapılmasını da üstlenmesi dikkat çekmektedir. ${ }^{58} 1863$ ortalarında cami minaresinin tamiri Todori Kalfa tarafından yapılmış ve 21.600 kuruş harcanmıştır. Ebru Türker günümüzdeki cami minaresinin Todori Kalfa tarafından yapıldığını ifade etse de bu minare caminin tamamen ve yeniden yapılması esnasında yıkılmıştır. ${ }^{59}$ Cami 1864 yılında yine önemli bir tamir daha geçirmiştir. 22.08.1864-26.11.1864 tarihleri arasında 3 ay süren bir tamiratın amele günlük çizelgeleri ile satın alınan eşyalara ait masraf defterine göre 24.421 kuruş harcama yapıldı̆̆ 1 görülür. ${ }^{60}$

1866 yılında Heci Yani Kalfa caminin bazı mahalleri ve minaresinin tamirinden başka Sultan Abdülaziz'in emriyle mahfil-i hümâyûnu da tamamen yıkıp yeniden yapmıştır. Mahfil-i hümâyûn tamiratı için 46.705 kuruş harcanmıştır. ${ }^{61} \mathrm{Bu}$ yıl içerisinde yine aynı kişiye Somuncuoğlu sokağından su hazinesine kadar olan suyolu ve diğer bazı mahallerin tamiri yaptırılmış karşılığında 1.700 kuruş ödenmiştir. ${ }^{62}$

1868 yılında Levend Çiftliğinden Taksim hattı üzerinden Galatasaray İdâdîsi ve birçok resmî kurumlarla birlikte aynı hat üzerinden getirilen cami suyolu tamir edilmiş ve her kurum kendi idaresince ödeme gerçekleştirmiştir. Cihangir Camisi adına her masurası ${ }^{63} 4.116$ kuruş evkaf hazinesinden karşılanmıştır. ${ }^{64}$ Ayrıca 1869 yılında cami cam ve çerçeveleri tamir edilmiştir. ${ }^{65}$

1870 yılı Kasım ayında Heci Yani Kalfa 1.700 kuruşa cami ve tuvaletlerde bir tamirat daha yapmış ancak parasının 1.400 kuruşunu 1871 Haziran ayında hala alamadığı anlaşılmaktadır. ${ }^{66}$ 1870'lerde Osmanlı Devleti'nin borçlarını ödeyemeyecek duruma gelmesinin her alanda

\footnotetext{
55 Şefaattin Deniz, “Teşvikiye Camisi'nin İnşaatı (1853-1854), Türk Dünyası Araştırmaları, 221, Nisan (2016): 168.

56 BOA.EV.MH. 689 / 72.

57 Havanen Dırağ, 1831-1900 Yılları Arasındaki İstanbul Yangınları, Basılmamış Mezuniyet Tezi, (İstanbul: İstanbul Üniversitesi İstanbul, 1977), 198.

58 BOA.EV.MKT. 184/ 226

59 BOA.EV.MKT. 215 /292; Türker, Mimarlık Tarihi, vii.

60 BOA. EV.d. 19128

61 VGMA. Defter 1809/37.

62 BOA.EV.MH. 1412/ 151; BOA.EV.MH. 1412/ 153

631 masura 9,19 mm veya 4,5 litre/dakika bkz. İzzet Kumbaracılar, İstanbul Sebilleri, (Ankara: Kültür Bakanlığı, 1938), 4. Kumbaracılar: "Bir buçuk dirhem kurşun, dört buçuk çekirdeğin ağırlığı kurşun ve bir çuvaldızın girebileceği delikten geçen suya masura tabir olunur" demektedir.

64 BOA.EV.MH. 1246/187; Kazım Çeçen, Istanbul'da Osmanlı Devrindeki Su Tesisleri, (İstanbul: İstanbul Teknik Üniversitesi, 1984), 4-5; Kumbaracılar, Istanbul Sebilleri, aynı yer.

65 BOA.EV.MH. 1376/579

66 BOA.EV.MH.1525/8; BOA.EV.MH. 1588/122
} 
hissedilir oluğunu küçük bir cami inşaatı dahi olsa ödemelerde güçlük çekildiği anlaşılmaktadır. ${ }^{67}$

Caminin bazı tamirlerinin ise cami personeli tarafindan gerçekleştirilmiştir. 1872 yllında cami kayyımı Osman Efendi minare sırıklarını ve kandil kutularını 96 kuruş masrafla tamir etmiştir. $^{68}$

Buraya kadar elde edilen veriler ve yapılan çalışmalar göstermiş̧tir ki; 1831-1900 yılları arasında neredeyse her yıl bir yangın vuku bulmuştur. ${ }^{69}$ Çoğunluğu ahşap olan evler yangının genişlemesine neden olduğu için yeniden yapılacak evlerin kârgir yapılması emredilmiştir. ${ }^{70} \mathrm{Bu}$ sebeple yanan evler, cami ve imam evi tümüyle kârgir olarak yapılmıştır. ${ }^{71}$ Ayrıca yukardaki verilerden anlaşılacağı üzere 1860 'larda eskiyen camide oldukça masraflı tamiratların gerçekleştirildiği anlaşılmaktadır. Bu nedenle Sultan Abdülaziz Han (1861-1876) caminin tümden yıkılarak yeniden yapılmasına karar vermiştir.

\subsection{Caminin yeniden yapılması}

Şimdiye kadar caminin bugünkü şeklinin de verilmiş olduğu yeniden yapılışı hususunda, cami kitabesinde yazılı olan 1889-1890 y1lında II. Abdülhamid tarafindan yeniden yaptırılmış olduğu bilgisi dışında bir bilgi bulunmamaktaydı. Bu yüzden cami ile ilgili tüm çalışmalar ve kayıtlarda doğal olarak bu bilgi esas alınmıştır. Ancak yaptığımız araştırma neticesinde yeni çıkan arşiv kayıtlarından öğrendiğimize göre caminin yeniden yapılması oldukça maceralı bir sürece dönüşmüsstür. $\mathrm{Bu}$ süreçten devletin bürokratik yavaşlığ ve ekonomik zor koşullar içerisinde olmasının cami inşaatını nasıl mahkemeye düşürdügünü görebilmek mümkün olmuştur. Caminin tamamen yıkılıp yeni tarzda yeniden yapılmasına Sultan Abdülaziz 21 Eylül 1873 tarihinde karar vermiştir. ${ }^{72} 1860$ 'lardan beri caminin bakım ve onarımlarını yapan Heci Yani Kalfanın da yüklenici olduğu bu yeniden yapılma hikayesinin başlamasında aynı yılın Ağustos ayında çıkan bir yangında cami kubbesi ve minare külahının yanmış olması etkili olmuştur. Illk önce kubbe ve minaresinin yeniden yapılması için yazışmalar yapılmışken Sultan Abdülaziz Han caminin tümden yıkılarak yeni bir tarzda minaresi ve kubbe aleminin uygun olacak şekilde yeniden yapılmasına karar verdiği görülür. ${ }^{73}$ Ekonomik sıkıntıların olduğu bir dönemde padişahın yeniden yapılmasını istemesinde, yukarıda ifade ettiğimiz gibi caminin oldukça yıpranmış olması, sık sık yangınlarda zarar görmesi ve en önemlisi de devrin yeni

\footnotetext{
67 Donald Quataert, "19. Yüzyıla Genel Bakış Islahat Devri 1812-1914", Osmanlı Imparatorluğu'nun Ekonomik ve Sosyal Tarihi, II, 6. bs. Editör: Halil İnalcık, Donald Quataert, (istanbul: Eren Yayıncılık, 2006), 898.

68 BOA.EV.MH. 1623/844

${ }^{69}$ Havanen Dırağ, 1831-1900 Yılları Arasındaki İstanbul Yangınları, Basılmamış Mezuniyet Tezi, (i̇stanbul: İstanbul Üniversitesi, 1977), 182-205.

70 BOA.EV.MH.TIK. $23 / 306$

${ }^{71}$ BOA.EV.MH.TIK 29/213

72 BOA.EV.MKT.906/268; BOA. I.DH. 673/46896; BOA. I.DH. 673/46909)

${ }^{73}$ BOA.I.DH. 1295/101767; BOA.MKT.MHM. 464/67; BOA.MKT.MHM. 464/18
} 
mimarı tarzına uygun bir şekilde kubbe ve minare külahlarının da kârgir olarak yaptırma isteğinin ağır bastığı anlaşılmaktadır.

23 Eylül 1873/30 Recep 1290 tarihli şehremanetine yazılan bir yazıyla 3000 keseye nezaretin gönderdiği yeni resme göre yapılması emredilmiştir. ${ }^{74}$ İnşaatın toplam maliyeti başta 1.713.839,5 kuruş olarak hesaplanmıştır. Eski kurşunların eritilmesi ve saire karşılığı 28.161 kuruş toplam maliyetten düşüldükten sonra kalan 1.685.678,5 kuruş inşaatın yeni maliyet masrafı olarak hesabedilmiştir. Yüklenici Heci Yani Kalfanın münakasa (eksiltme) yöntemiyle 185.678,5 kuruş indirim yaptıktan sonra caminin nihai maliyeti 1.500 .000 kuruş olarak öngörülmüşsür. ${ }^{75}$ Her şey güzel başlamış olsa da inşaatın başına gelmedik kalmamıştır. Yıllardır tamir ve bakımlarını yüklenici olarak yapan Heci Yani Kalfa bu inşaatı, tabir yerindeyse aldığına pişman olmuştur. İlk başta cami temelinden çıkan molozların Gasilhane meydanına birçoklarının da attığı gerekçesiyle atılması yasaklanmıştır. ${ }^{76}$ İkinci aksaklık ise inşaata başlanması için keşif defterinin bir türlü gönderilememesi olmuştur. ${ }^{77}$ İhaleden neredeyse 5 ay sonra 09.02.1874/ 21 Z. 1290 tarihli bir arzuhalden inşaata başlanabildiği anlaşılmaktadır. Bir de Yani Kalfanın inşaata başlangıç masrafları için verilecek olan 100.000 kuruş yerine yarısı 50.000 kuruş verilmiştir. ${ }^{78}$ 23.04.1874/6 Ra. 1291 tarihli bir kayda göre verilen bu 50.000 kuruş hafriyata harcanmış ve gerekli malzemelerin alınması için her iki haftada 15.000 kuruş olmak üzere 200.000 kuruş verilmesine karar verilmiştir. ${ }^{79}$ Başka bir arşiv kaydında da 1872/1289 tarihine mahsuben 200.000 kuruşun ödendiği anlaşılmaktadır. ${ }^{80}$ Bundan sonra küçük aksaklıklar yaşansa da cami inşaatı 1875 Temmuz'una kadar sorunsuz devam etmiştir. Yükleniciye Eylül 1874- Temmuz 1875 tarihleri arasında çeşitli zamanlarda 180.000 kuruş ödeme yapılmıştır. ${ }^{81}$ Bir ara suyun kesilmesinden ötürü inşaat bir iki gün tatil edilmiş ancak inşaatın durdurulmasının münasip olmadığı şeklinde uyarı bile yapılmıştır. ${ }^{82}$ Fakat bu tarihten sonra ters giden bir şeyler olmuştu ki ardı ardına keşif raporları hazırlatılmıştır. İki yıl zarfında inşaatın hangi aşamada olduğu ile ilgili ilk keşif raporu 14.02.1876/1291 tarihinde uzman kalfalar tarafından yapılmıştır. Bu rapora göre minareler hariç başlangıçta öngörülen cami maliyetine göre üçte biri bile tamamlanmamış olup 545.000 kuruş harcanmıştır. ${ }^{83}$ Buna yakın başka bir keşif raporuna göre de yine şimdiye kadar yapılan yerlerden keşif dâhilinde olan yerler için 534.114,5 kuruş, keşif haricinde 294.141,5 kuruş harcandığı, kalan kısımlar için ise 828.256 kuruş harcanacağı rapor edilmiştir. Bu rapora göre de toplam keşif bedelinin 1.500.000 kuruş olduğu düşünüldüğünde 156.512 kuruş

${ }^{74}$ BOA.EV.MKT. 694/344.

${ }^{75}$ VGMA, Defter. 2706/109

${ }^{76}$ BOA.EV.MKT. 709/83.

77 BOA.EV.MKT. 702/228

${ }^{78}$ BOA.EV.MH.1695/200

${ }^{79}$ BOA.EV.MH.TIK. 18/392

${ }^{80}$ BOA.EV.MH.1723/77.

${ }^{81}$ BOA.EV.MH. 1794/66

82 BOA.EV.MH.TIK. 23/296

83 BOA.EV.MH.TIK. 22/285 
fazlasıyla toplam masraf 1.656 .512 kuruşa çıkmış oluyordu. ${ }^{84}$ 28.10.1876/ 16 Teşrinievvel 1292 tarihli üçüncü raporda ise şimdiye kadar yapılan masrafların 711.965 kuruş, bundan böyle yapılacak olanın ise 788.035 kuruş olacağı, toplamı da 1.500 .000 kuruş olarak kaydedilmiştir. ${ }^{85}$ Bu raporlardan da anlaşıldığı gibi 1876 yılı Mart ayı itibariyle cami inşaatının hemen hemen yarısı tamamlanmış olduğu halde neden bu şekilde bir rapor hazırlatıldığının iç yüzünü yüklenici Heci Yani Kalfanın 15.06.1875 tarihli inşaatı durdurduğuna dair arzuhali göstermektedir. Yüklenici Heci Yani Kalfanın verdiği arzuhalinde üç ana sebepten inşaatı durdurduğu anlaşılmaktadır. Birincisi ve en önemli sebep başlangıçta metalik akçe üzerinden alacağı paranın kaime 100 kuruş üzerinden verilmesidir. ${ }^{86}$ İkincisi, başından beri keşif harici olarak resen yaptığı işlerin kontrata bağlanması. Üçüncüsü de ilk başta cami resmi ile birlikte çizilen resimden farklı olarak yapılması istenen minare resminin yeni bir keşifle ek kontrata bağlanmasını istediği halde bunun bir türlü gerçekleştirilmemesidir. Aslına bakılırsa inşaatın durmasında en etkili sebebin para meselesi olduğunu, Yani Kalfanın keşif harici yapmış olduğu işleri inşaatı durdurmaya görünür sebep olarak öne sürdüğünü söyleyebiliriz. Zira temel kazarken zemin çürük çıktığı için daha derin bir temel kazarak 18 zira $(13,5 \mathrm{~m})$ derine inmesi çok da sorun olacak bir sebep gibi görünmemektedir. Ama keşif haricinde resen bir sarnıç ve birkaç oda daha yapmış olması ile padişahın başlangıçta cami resmi ile birlikte çizilen resimden farklı bir minare resmi çizdirerek onun yapılmasını istemes ${ }^{87}$ yeniden bir keşif yapılmasını gerektirmiş olduğundan önemli bir sebep gibi görülebilir. Yine de tüm inşaatın durdurulmasına bir sebep olmaması gerekirdi. Temel sorun aslında bürokrasinin yavaşlığı kontrat yapılmasını geciktirip üstüne bir de kendisine metalik akçe yerine kaime üzerinden para ödemesi yapılınca işleri iyice zora sokmuştur. Bunun üzerine Heci Yani Kalfa da inşaatı tamamen durdurma kararı almıştır. İnşaatın neredeyse yarısına kadar getiren Yani Kalfa sonunda 15.06.1875 /11 Ca 1292 tarihinde verdiği arzuhalde durumu izah ederek şehremanetine bildirilmesini istemiştir. ${ }^{88}$

$\mathrm{Bu}$ arzuhalden sonraki yazışmalara göre inşaat 1875 Haziran'ından itibaren durmuştur. 24.07.1876/3 Recep 1293 tarihinde keşif defterinde kuruş rayici belli olmadığından şehremanetine sorulması gerekmiştir. Buradaki sorun ödenecek paranın metalik mi yoksa kaime üzerinden mi olduğunun keşif defterinde net olarak belirtilmemiş olmasından kaynaklanıyordu. ${ }^{89}$ Heci Yani Kalfanın asıl sorunu da buydu zaten. Kuruş rayicinin anlaşmadan farklı olarak metalik akçe yerine kaime üzerinden ödeme yapılmasıydı. Bu meselenin aslında ülkenin içinde bulunduğu mali durumla doğrudan ilişkisi olduğu bellidir. Kaime daha önce kaldırıldığı halde bu sıralarda yeniden piyasaya sürülmüştür. Osmanlı Devleti bir yandan 1873 yılında ortaya çıkan Avrupa ve Amerika mali piyasalarındaki sıkıntıdan dolayı dış borçlanma gerçekleştirememiş

\footnotetext{
${ }^{84}$ VGMA, Defter 2706/109

${ }^{85}$ BOA.EV.MH.TiK. 31/280.

86 BOA.EV.MKT. 906/272

87 BOA. A.MKT.MHM 464/67; A.MKT.MHM 464/18

88 BOA.EV.MKT. 790/ 302

89 BOA.EV.MKT. 829/87
} 
1875-1876 yıllarında dış borç ödemesini durdurmuştur. Bir de bu yıllarda kaime ve altın lira değerinde değişim yaşanmaktayd.$^{90} \mathrm{Bu}$ durumun yüklenicinin kafasını karıştırmış olduğu oldukça anlaşılır gözükmektedir. Heci Yani Kalfanın neye güvenerek bu şekilde bir rest çektiğini kestirmek zor olsa da muhtemelen devletin bu şartlarda başkasına ihale etmesinin mümkün olmadığını düşünmüş̧ü.

Merkezi yönetim cephesinden inşaatın durmasına tepki öncelikle sert oldu. Heci Yani Kalfayla yapılan kontratı feshedip başka bir yüklenici olan Yeni Dünya Kalfanın daha uygun bir fiyatla inşaatı yapacağını taahhüt etmesiyle işin ona ihale edilmesi gündeme getirildi. $\mathrm{Bu}$ durumun olacağını hiç tahmin etmemiş olamayacağını düşündüğümüz Heci Yani Kalfa iskele masrafları ve keşif harici harcamalarını mahkeme yoluyla almaktansa daha cazip bir teklif vererek ihalenin yine kendisinde kalması için elinden geleni de yapmıştır. Bu şekilde sonuçlanmasında yetkililerin, Heci Yani Kalfanın açacağı davalarda hazinenin daha zararlı çıkacağı, yaptığı iskele masrafları ve keşif harici masraflarını alabilmek için cazip bir teklif vererek ihaleyi tekrar almaya çalışan Heci Yani Kalfayla ortak noktada buluşmanın daha doğru olacağı düşüncesinin hâkim olması etkili olmuştur. Böylece iki tarafın da istediği gibi oldu ve ihale tekrar Heci Yani Kalfada kaldı. ${ }^{91}$ Bu sonuca göre devlet yetkililerinden birilerinin, Heci Yani'nin Dimyat'a pirince giderken evdeki bulgurdan olacaktı gibi bir düşünceye kapılanları olmuş ise oldukça yanılmış olduklarını zaman gösterecekti.

Bunlar olup biterken meselenin hiç de kolay bitmeyeceği anlaşılmış olmalı ki caminin yapılan mahallerinin zarar görmemesi için örtü yapılması gündeme gelmiştir. 06.12.1876/19 Z. 1293 tarihinde şimdiye kadar yapılan yerlerin kış ayından zarar görmesini engellemek için bir çaba söz konusu olmuş ise de bürokrasinin hantallığı kışın hızına yetişememiştir. Keşif yapılarak bir örtü yapılması için alınan karardan sonra bir kış bir de yaz geçmiş olduğu halde hala örtünün yapılamadığı anlaşılmaktadır. ${ }^{92}$ Hatta 18.06.1877/7 C. 1294 ve 01.11.1877/24 L. 1294 tarihli yazılardan anlaşıldığı üzere yarım kalan inşaat ve iskeleleri, üç yaz iki kış geçirmiş ama hala üzerine yapılacak örtüyü beklemekteydi. ${ }^{93}$

Tekrar ihale meselesinde dönecek olursak Heci Yani'nin hiç de yabana atılacak bir müteahhit olmadığı deyim yerindeyse adeta piyasanın kurdu olduğu anlaşılmaktadır. Meğer yeniden ihaleyi alabilmek için inşaatı durdurma gerekçesinden vaz geçtiğini söyleyip hesaplaşmayı bir süre ertelemeyi düşünmekteymiş. 26.05.1878/24 Ca. 1295 tarihli bir kayıtta da görüldüğü gibi Heci Yani cami inşaatını başlarda metalik akçe üzerinden anlaştığı halde kendisine kaime 100 kuruş hesabıyla ödeme yapılmasından dolayı inşaatı durdurduğu halde kaime 100 kuruş hesabıyla yine kendisi tamamlayacağını taahhüt ederek ihalenin kendisinde

\footnotetext{
90 Şevket Pamuk, Osmanlı Imparatorluğu'nda Paranın Tarihi, (İstanbul: Tarih Vakfı Yurt Yayınları, 1999), 231-232; Diyanet İslam Ansiklopedisi, Ali Akyıldız, (İstanbul: İslam Araştırmaları Merkezi, 2001), 24. cilt. "Kaime" maddesi, 212215.

${ }^{91}$ BOA.EV.MKT. 842/10.

92 BOA.EV.MKT. 842/92.

${ }^{93}$ BOA.EV.MKT.CHT.92/46; EV.MKT. 880/294.
} 
kalmasını sağlamıştır. ${ }^{94}$ Sonra da 24.08.1878/ 22 Ş. 1295 tarihli Adliye Nezareti'nin bir yazısından anlıyoruz ki Heci Yani'nin kurnaz bir yol izleyerek önce "kabul ettim" dediği halde şimdi de kaime yüz kuruş hesabından ödenmesini kabul etmeyeceğini beyan ederek Evkaf-1 Hümâyûn Nezaretini dava etmiştir. ${ }^{95}$ Yani iki ay geçmeden sözünden dönmüş, olayı mahkemeye taşımıştır. İki taraf arasındaki bu dava bir buçuk yıl sonra 16.02.1880/5 Ra. 1297 tarihinde ikinci hukuk dairesine havale edilmiştir. Sonra bu daire davayı görüşmek üzere kontratosu ile keşif defterini istemiştir. ${ }^{96}$ Işsler yoluna girecek diye beklerken iyice arap saçına dönmüş cami inşaatına bir türlü tekrar başlanamamıştır.

Yüklenici ve Evkaf Nezareti arasındaki davanın altında yatan asıl sebebin daha önce de ifade edildiği gibi devletin 1870 ve 1880 yılları arası mali zorluk içinde bulunmasıydı. ${ }^{97}$ Bunu somut bir örnek olacağını düşündüğümüz 1880 yılına ait bir belgeden çıkarmak mümkündür. Ocak ayı kayıtlı belgeye göre Altıncı Belediye Dairesi dahilinde bulunan bazı cami, hayrat ve Müslüman kabirleri arsalarının satılarak Cihangir Camisi'nin tamamlanmasına karar verildiği görülmektedir. ${ }^{98}$ Bu karardan sonra inşaatta bir hareketlilik göze çarpmaktadır. 29.04.1880 /19 Ca. 1297 tarihinde Heci Yani Kalfa ikmal inşaatına başladığını beyan ederek 5 yük (500.000) kuruş metalik akçe 1 Osmanlı Lirasının 106 kuruş hesabıyla inşaatı tamamlayacağı, inşaat başlayacağ için ilk etapta 100.000 kuruşun kendisine verilmesini talep etmiştir. Görüldüğü gibi Heci Yani paranın kaime üzerinden değil de metalik akçe üzerinden alma hususunda kazançlı çıkan taraf olmuştur. Verdiği arzuhal üzerine düşülen uzun bir değerlendirmeden anlaşıldığına göre sütten ağzı yanan yetkililer yoğurdu üfleyerek yemeye başlamıştır. Belgede şu noktalara dikkat çekilmiştir: Öncelikle ikmal inşaatının keşif defterine göre yapılması eksik yapılmaması, fazla yapılır ise fazlasinın talep edilmemesi, talep olunur ise mahkeme-i şeriyye ve nizâmiye dairelerince itibar olunmamasl, mukaveleden vazgeçilir ise hesaptan \%10 kuruş kesilmesi. Yüklenicinin inşaatı tamamlayacağına dair beyanından sonra ödemelerin bina yapıldıkça hazineden metalik akçe üzerinden parça parça yapılacağı da belirtilmiştir. ${ }^{99}$

Fakat yine inşaatın başlayacağı beklenirken bir yıl iki ay geçmesine rağmen hala başlamamıştı. 30.06.1881/ 3 Ş. 1298 tarihinde yarım kalan inşaatın iskele ve kereste ve sairesinin keşif muayenesi düzenlenerek gönderilmesi istenmiştir ki inşaata başlanabilsin. ${ }^{100}$ Birçok kez yapılan yazışmadan ve Şurayı Devlet'te yapılan görüşmelerden sonra iskele ve kereste ve sairenin keşfi yapılarak ne kadar masraf olduğu bir yıl iki ay geçtikten sonra 18.08.1882/4 L. 1299 tarihinde gerçekleştirilebilmiştir. Buna göre keşif bedeli 1 Lira 100 kuruş hesabıyla 23.873

\footnotetext{
94 BOA.EV.MKT. 906/272

95 BOA.EV.MKT. 919/59

96 BOA.EV.MH. 2031/262

97 Quateart, "Islahatlar Devri”, 898.

98 BOA.I.DH.. 798 / 64708

99 BOA.EV.MH. 2038/182

100 BOA.EV.MKT. 1103/234
} 
kuruş olarak gerçekleşmiş̧ir. ${ }^{101}$ Ağustos'ta gerçekleşen bu keşiften sonra da ikmal inşaatı bir türlü başlamayınca sonunda 10.12.1882 / 29 M. 1300 tarihinde dikkat çeken ve yöneticileri harekete geçirmede etkili bir rol oynayan vatandaş araya girmiştir. Mahalle esnafi ve sakinleri imza kampanyasına benzer bir organizeyle 51 kişinin mührü olan bir arzuhal vermişlerdir. Arzuhalde mahallede bulunan caminin 8-9 sene önce yandığı için irade-i seniyye ile kârgir olarak yapılmasına karar verildiği ve büyük çoğunluğu (kısm-1 âzamîsi) yapıldı̆̆ 1 halde tamamlanmadığı ve yapılan inşaatın kışın etkisiyle daha çok zarar göreceği, cuma namazının edasında sıkıntı çektiklerinden bahsetmişlerdir. ${ }^{102}$ Bunu dikkate alan yetkililer sonunda 15.06.1875 tarihi ve 06.02.1883 tarihleri arasında geçen 6 yıl 8 ay gibi bir süre fiili olarak duran inşaatın başlanmasına dair onay yazısını 06.02.1883/27Ra.1300 tarihinde yazmışıtır. 14.08.1883/10 L. 1300 tarihinde yüklenicinin talep ettiğine bakılırsa inşaata başlanmış ve devam etmektedir. ${ }^{103} 22.09 .1883 / 20$ Za. 1300 tarihinde de yaklaşan kış mevsiminde yapılan yerlerin zarar görmemesi için kalfanın istediği 197.000 kuruş Evkaf meclisinde onaylanmış ve hazineye bildirilmiştir. ${ }^{104}$ Bundan sonra yapılan birçok yazışma ve 07.12.1884/18 S. 1302 tarihli bir arşiv kaydında aydan aya 50.000 kuruş para ödemeleri gerçekleştirilmiştir. ${ }^{105} 1885$ yılına ait bir fotoğrafta iskele seviyesine bakılırsa inşaatın henüz kubbesinin yapılmadığı görülebilmektedir. ${ }^{106}$

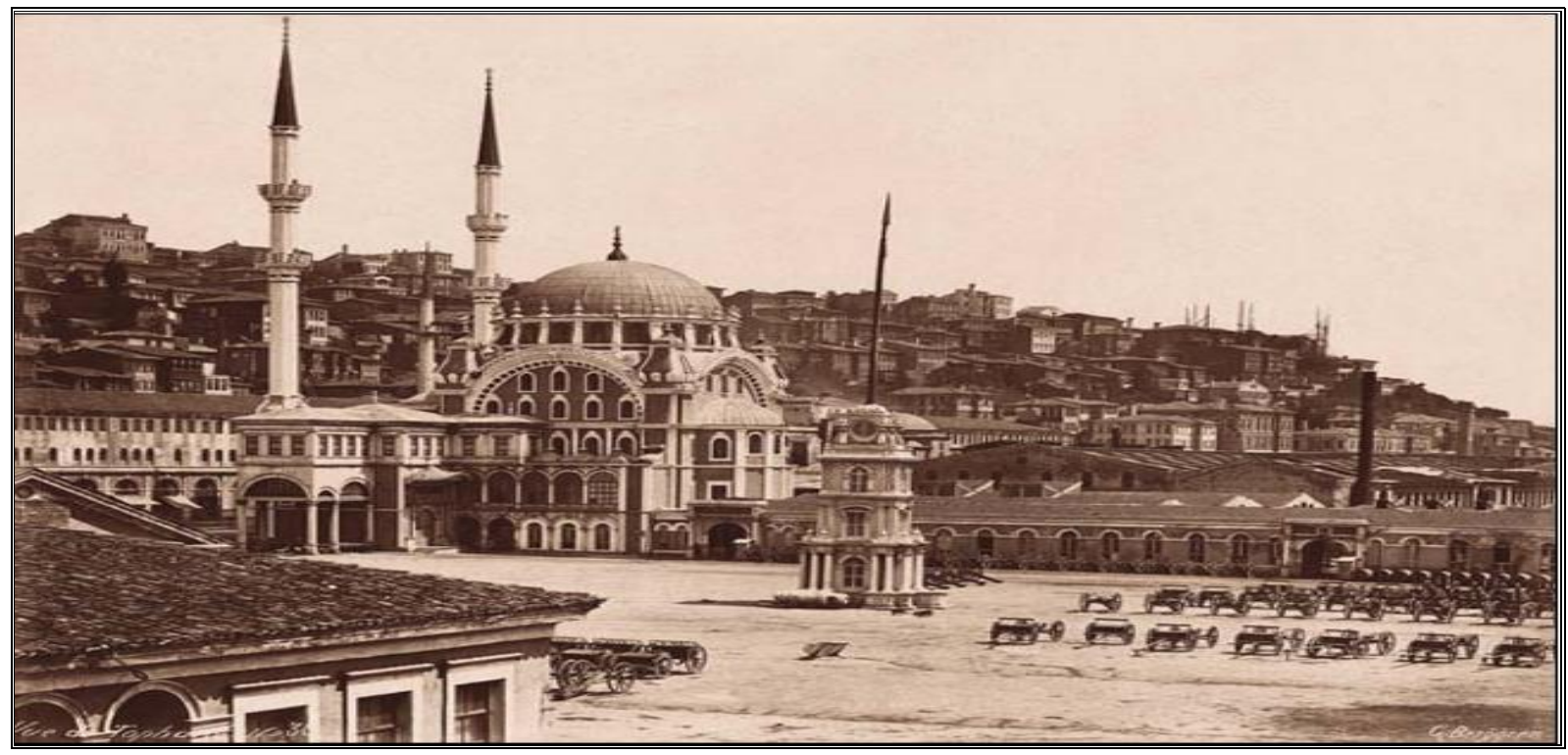

Resim 7: Guillaume Gustave Berggren'e ait Nusretiye Camisi fotoğrafında sağ üstte Cihangir Camisi yapımı için kurulan iskele, 1885 (Türker, Mimarlık Tarihi, 69).

\footnotetext{
101 BOA.EV.MKT. 1167/244.

102 BOA.EV.MKT. 1178/242

103 BOA.EV.MKT. 1240/ 190

104 BOA.EV.MKT. 1240/192

105 BOA.EV.MKT. 1296/2

106 Şekil 8.
} 
21.02.1886/17 Ca. 1303 tarihli bir yazıda karar verilip yeniden başlanan cami inşaatının yapılan yerlerinin kıştan zarar görmemesi için kurşunlarının örtülmesi gerektiğinden bahsedilmiştir. ${ }^{107}$ Cami kurşunlarına yapılan masraflara bakılırsa kubbesinin 1887 ortalarına doğru örtüldüğünü söyleyebiliriz. ${ }^{108}$ 14.04.1889 tarihinde cami bahçe duvarlarının yapımı keşif içinde miydi yoksa değil miydi tespit edilene kadar kalfa tarafindan yapılıp bitirilmiştir. ${ }^{109}$ Anlaşılan o ki kalfa da herkes gibi artık bir an önce bitirmek niyetindeydi. Zaten hazinenin mali durumu o kadar kötü olduğundan Evkaf için ayrılan para görevlilerin maaşına bile yetmiyordu. Tamiri bekleyen birçok mabetle birlikte ikmal inşaatının kalan kısımların tamamlanması için para bir türlü alınamıyordu. ${ }^{110} 14.05 .1889 / 14$ R. 1306 tarihli bir yazıdan duvarıyla ilgili hesabın keşif defterini aşıtı̆ından yeniden şehremaneti memurlarına havale edilmişti. ${ }^{111}$ Çevre duvarı kimin üzerine kaldı bilinmez ama cami 1890 Nisan ayına denk gelen Ramazan'da cemaatle namaz kılınacak seviyeye gelmişti. Sadece minberinin tamiri nedeniyle birkaç ay daha gecikerek temmuz ayında tam hizmet vermeye başlamıştır. ${ }^{12}$

Böylece uzun bir hikayeye dönüşen Cihangir Camisi'nin yeniden yapılma serüveni 21.09.1873 tarihinde başlamış 15 y1l 7 ay sürerek 20 Nisan 1890 Ramazan'ında bitmiştir.

\section{Cami ait diğer bazı bilgiler}

Kanuni'nin vakfı olan Cihangir Camisine ayrı bir gelir tahsis edilmeden her türlü giderleri Süleymaniye Vakfı masrafları içerisine dahil edilerek vakıf gelirlerinden karşılanmıştır. ${ }^{113} \mathrm{Cami}$ yönetiminde birinci derecede imam sorumlu olmuştur. Resmi yazışmalarda imam-1 evvel mührü ve imzasını kullanmıştır. ${ }^{114}$ Cami ve mahalle ilişkisi açısından iyi bir iletişim kurulduğu kaynaklara yansımıştır. ${ }^{115}$

Vakfiyede Caminin işleyişi için gerekli olan bedeni ve dini hizmete dönük 15 farklı cihet ${ }^{116}$ vardır. Ancak zamanla yeni cihetler ihdas edilmiş bu sayı 22'ye çıkmıştır. ${ }^{117}$ Arşiv kayıtlarına göre her cihet için bir personel görevlendirilmesi gerekmemiştir. Birçok ciheti bir personel yerine getirmiştir. Mesela XIX. yüzyıl başlarında camide 5 personel tüm cihetleri yerine getirmekteydi. Daha açık bir ifadeyle hatip aynı zamanda imamlık cihetini, hatta mektep hocalığını ve çeşitli

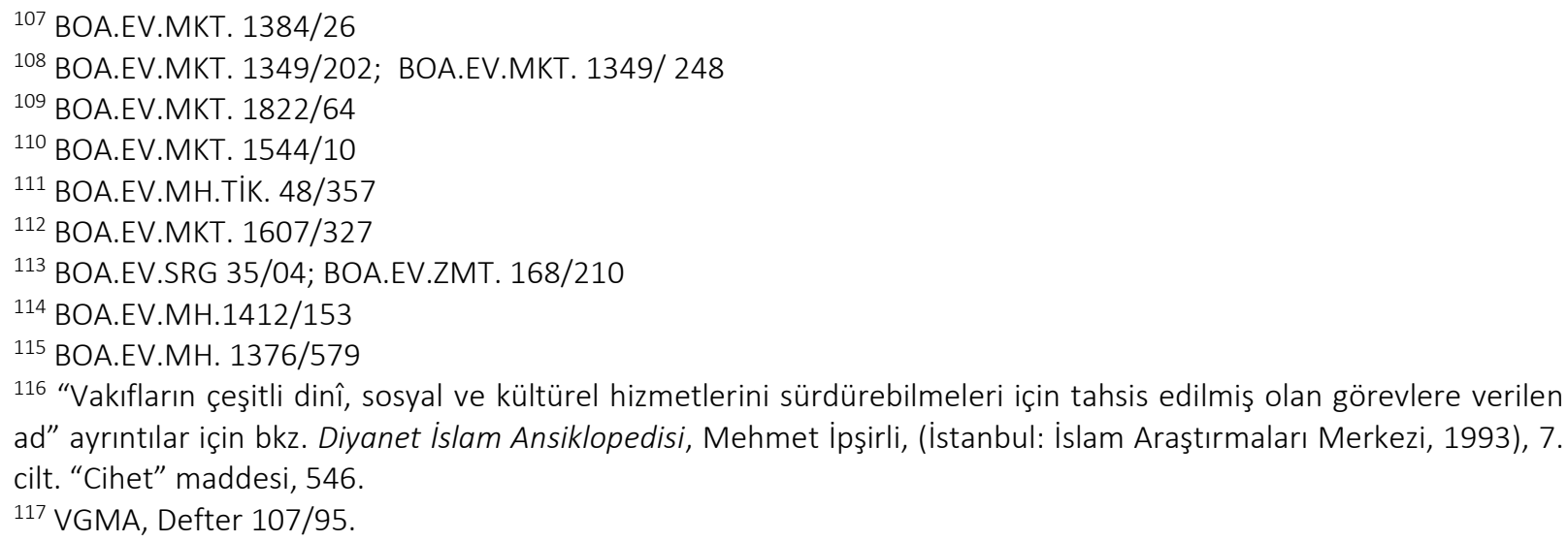


temizlik işlerine ait cihetlere de mutasarrıf olmuştur. ${ }^{118}$ Bunların dışında cami personeli bu cihetler karşılığında Süleymaniye İmareti’nden birer çift fodula (ekmek) almışlardır. ${ }^{119}$ Genel itibariyle cami personeli hatip, ${ }^{120}$ İmam, ${ }^{121}$ muezzin, ${ }^{122}$ devirhan ${ }^{123}$ (hafiz), ${ }^{124}$ muarrif, ${ }^{125}$ sermahfil, ${ }^{126}$ kayyım, ${ }^{127}$ siraci, ${ }^{128}$ muallim-i mektep ve halife-i mektep, ${ }^{129}$ buhuri ve harc-1 buhur, ${ }^{130}$ muvakkit, ${ }^{131}$ ferrâş-1 mektep ve ferrâş-1 kenif, ${ }^{132}$ ferrâş-1 seccade-i vâiz-i Cuma, ${ }^{133}$ râhâbi (suyolcu) ${ }^{134}$ gibi görevlilerden oluşmaktaydı.

Caminin aydınlatılması için aylık 75 vukiyye ${ }^{135}$ balmumu Süleymaniye imareti tarafından temin edilmiştir. ${ }^{136}$ Vakfiyeye göre yıllık 19.470 akçe personel maaşlarına harcanırken aydınlatma için yıllık 900 vukiyye yaklaşı 1 ton $155 \mathrm{~kg}$. balmumu imal edilmiştir. ${ }^{137}$

XVI. Yüzyıldan beri cami avlusunda bulunan Hasan Burhaneddin Cihangiri zaviyesi ve cami iki ayrı vakfa tabi olup ayrı gelirleri ve masrafları olmuştur. Cami ve Zaviye aynı mekânı paylaşmış olsalar da yönetim ve mali açıdan birbirinden tamamen ayrı kalmışlardır. Zaviye şeyhliği cami yönetimi ile hiçbir şekilde birleştirilmemiştir. Hatta imamlığa geçici bir süre

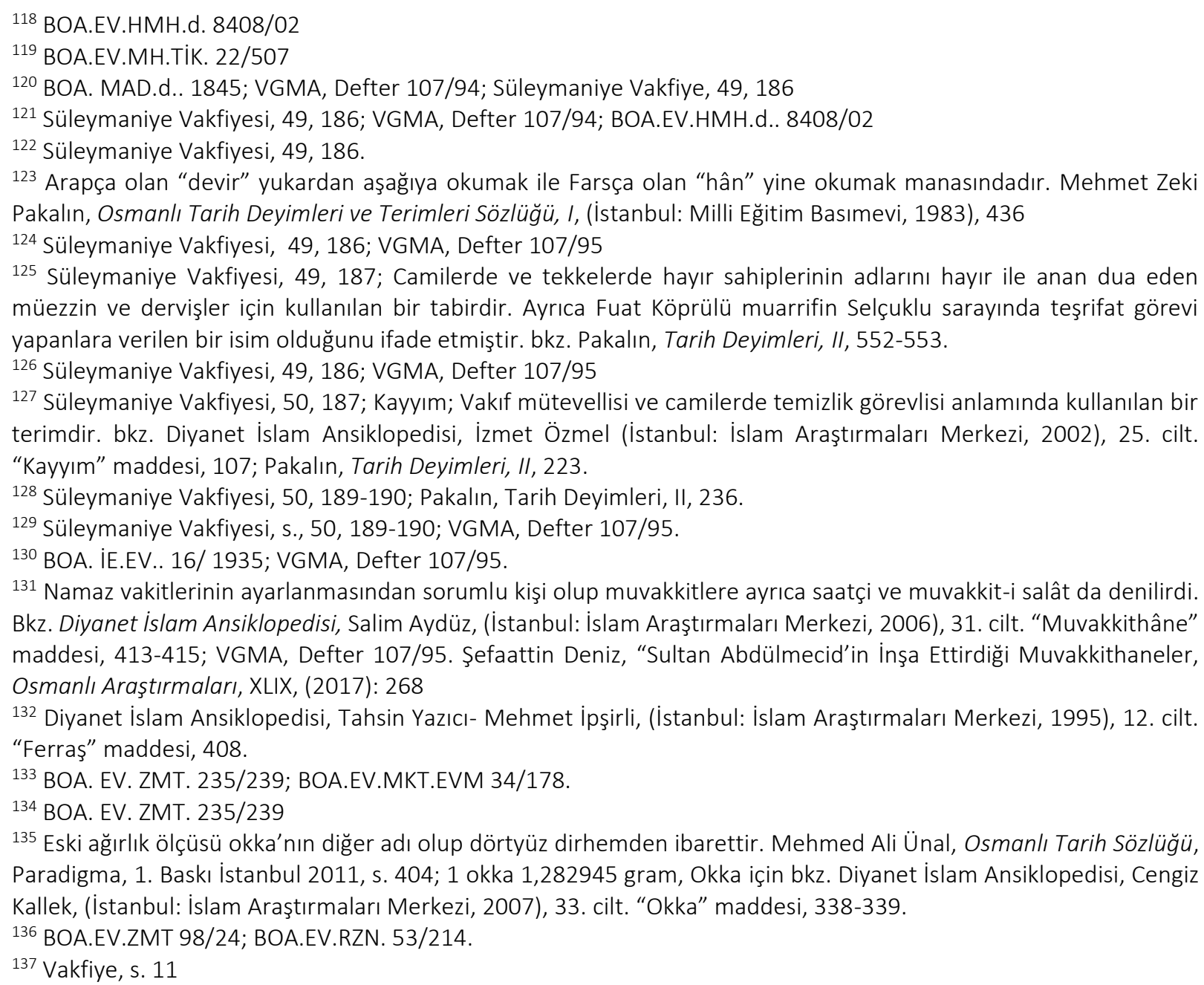

127 Süleymaniye Vakfiyesi, 50, 187; Kayyım; Vakıf mütevellisi ve camilerde temizlik görevlisi anlamında kullanılan bir terimdir. bkz. Diyanet İslam Ansiklopedisi, İzmet Özmel (İstanbul: İslam Araştırmaları Merkezi, 2002), 25. cilt. "Kayyım" maddesi, 107; Pakalın, Tarih Deyimleri, II, 223.

128 Süleymaniye Vakfiyesi, 50, 189-190; Pakalın, Tarih Deyimleri, II, 236.

129 Süleymaniye Vakfiyesi, s., 50, 189-190; VGMA, Defter 107/95.

130 BOA. IE.EV.. 16/ 1935; VGMA, Defter 107/95.

${ }^{131}$ Namaz vakitlerinin ayarlanmasından sorumlu kişi olup muvakkitlere ayrıca saatçi ve muvakkit-i salât da denilirdi. Bkz. Diyanet İslam Ansiklopedisi, Salim Aydüz, (İstanbul: İslam Araştırmaları Merkezi, 2006), 31. cilt. "Muvakkithâne" maddesi, 413-415; VGMA, Defter 107/95. Şefaattin Deniz, "Sultan Abdülmecid'in İnşa Ettirdiği Muvakkithaneler, Osmanlı Araştırmaları, XLIX, (2017): 268

132 Diyanet İslam Ansiklopedisi, Tahsin Yazıcı- Mehmet İpşirli, (İstanbul: İslam Araştırmaları Merkezi, 1995), 12. cilt. "Ferraş" maddesi, 408.

133 BOA. EV. ZMT. 235/239; BOA.EV.MKT.EVM 34/178.

134 BOA. EV. ZMT. 235/239

135 Eski ağırlık ölçüsü okka'nın diğer adı olup dörtyüz dirhemden ibarettir. Mehmed Ali Ünal, Osmanlı Tarih Sözlüğü, Paradigma, 1. Baskı İstanbul 2011, s. 404; 1 okka 1,282945 gram, Okka için bkz. Diyanet İslam Ansiklopedisi, Cengiz Kallek, (İstanbul: İslam Araştırmaları Merkezi, 2007), 33. cilt. “Okka” maddesi, 338-339.

136 BOA.EV.ZMT 98/24; BOA.EV.RZN. 53/214.

137 Vakfiye, s. 11 
vekâlet edilmesine bile izin verilmemiştir. ${ }^{138}$ Camisi Süleymaniye Vakfı tarafından finanse edilirken Hasan Burhaneddin Dergâhı masrafları için Tekfurdağı gümrüğünden senelik otuzbeş kuruş, Bahçekapısı Valide Sultan Vakfindan günlük beş akçe ve Evkâf-1 Haremeyn muhasebatından İstanbul Gümrüğü’nden taâmiye varidatından finanse edilmiştir. ${ }^{139}$ İki kurum personeli arasında bazen gerginliklerin yaşandığı kaynaklara yansımıştır. ${ }^{140}$

\section{Sonuç}

$\mathrm{Bu}$ çalışmayla caminin üç farklı şekline dair bilgilere ulaşılmış olup ilk şeklinin 1823 yılına kadar tamir edilerek ayakta kaldığı, ikinci şeklinin 1873 yılına kadar, üçüncü şeklinin de günümüze kadar devam ettiği anlaşılmıştır. 1873 Ağustos ayında yeniden yapılmasının Sultan Abdülaziz'in kararı olduğu, inşaatın çeşitli sebeplerden $1875^{\prime}$ te durup uzun bir aradan sonra tekrar 1883 yılında ikmal inşaatına başlanıp 1890 Nisan (Ramazan) ayında ilk namaz kılınarak ibadete tekrar açılmıştır. Böylece XVI. yüzyıldan beri ayakta kalan bir tarihi eserin bir dönemi daha aydınlatılmışıı. Aynı zamanda küçük bir cami tarihi çerçevesinde Devleti Aliyye'de mali zorlukların devlet nezdinde yapılan inşaatlara ve para politikasının bu sektördeki etkilerine dair bilgiler yanında, halk nezdinde bitirilemeyen bir cami inşaatı algısına dair verilere ulaşılmıştır. Ayrıca bu çalışma zengin arşiv kaynaklarımızın küçük bir cami inşaatı çerçevesinde bile idari, mali, sosyal ve hukuki sistem hakkında önemli bilgilere ulaşma imkânı sunduğunu göstermiş̧tir. Tarihi mirasın korunması ve onların gelecek nesillere aktarılması bu tür monografik ve analitik çalışmaları gerekli kılmaktadır. Bunların gün yüzüne çıkarılmasını bekleyen milyonlarca arşiv kaydı da araştırmacıların onlara nüfuz etmesini beklemektedir.

\section{Arşiv Kaynakları}

Vakıflar Genel Müdürlüğü Arşivi (VGMA)

Defterler: 1809/37; 8/59; 438/34; 1781/7; 2706/109; 107/94.

Başbakanlık Osmanlı Arşivi (BOA)

Cevdet Evkaf (C.EV): 598/30177.

Evkaf Defterleri (EV.d.): 19128;

Evkaf Muhasebe (EV. MH.): 689/72; 1805/70;.1376/579; 1525/8; 1588/122; 1623/844; $1695 / 200 ; 1805 / 74 ; 233 / 116$.

Evkâf Nezâreti Muhasebe Kalemi Tamirat ve İnşaat Kalemi (EV.MH.Tí): 22/507; 109/189; 18/392; 23/296; 23/306; 29/213; 30/66; 31/280.

\footnotetext{
138 VGMA, Defter 4645/156

139 VGMA, Defter 438/34; VGMA, Defter 1328/34; C. EV. 492415

${ }^{140}$ BOA.EV.MKT. 1878/76
} 
Evkaf Sergi Halifeliği (EV.SRG.): 106/328; 241/188; 270/50; 28/178; 44/9.

Evkâf-Evkâf Muhâsebesi (EV.EMH.TİK.): 161/161; 161/209.

Evkâf-Zimmet Halifeliği (EV.ZMT.): 235/239; 82/194.

Maliyeden Müdevver Defterler (MAD. d.) 1845

Mektubi Kalemi Cihat (EV. MKT. CHT.) 830/52.

Mektubi Kalemi (EV.MKT.) 1167/244; 1178/242; 1349/202; 1384/26; 1544/10; 1607/327; 1822/64; 17/303; 17/305; 1878/76; 24/217; 737/278; 880/294; 906/272; 919/59.

Sadâret Mektubî Kalemi Mühimme Kalemi Belgeleri (A.MKT.MHM): 464/67; 464/18.

\section{Diğer Kaynaklar}

Ahmet Cevdet Paşa. Tarih-i Cevdet. 12. cilt., İstanbul: Üçdal Neşriyat, 1974.

Aslanapa, Oktay. Osmanlı Devri Mimarisi. İstanbul: İnkılap Kitapevi, 1986.

Ayvansarâyi Hüseyin Efendi. Hadikatü'l-Câvâmi. Haz. Ahmed Nezih Galitekin, İstanbu: İşaret Yayınlar1, 2001.

Banoğlu, Niyazi Ahmet. İstanbul Cehennemi Tarihte Büyük Yangınlar. İstanbul: Kapı Yayınları, 2008.

Can, Selman. Bilinmeyen Aktörleriyle Son Dönem Osmanlı Mimarlı̆̆ı. Erzurum: Erzurum İl Kültür ve Turizm Müdürlüğü, 2010.

Çeçen, Kazım. İstanbul'da Osmanlı Devrindeki Su Tesisleri. İstanbul: İstanbul Teknik Üniversitesi, 1984.

Çetintaş, Sedat. İstanbul ve Mimari Yazıları. Ankara: Türk Tarih Kurumu, 2011.

Deniz, Şefaattin. "Sultan Abdülmecid'in İnşa Ettirdiği Muvakkithaneler, İstanbul: Osmanlı Araştırmaları, 49. Sayı, (2017): 267-291.

Deniz, Şefaattin. “Sultan II. Mahmud'a Ait İki Vakıf Eser: Arabacılar Kışlası ve Nusretiye Camileri”. İstanbul: Türk Dünyası Araştırmaları, 218. Say1, Ekim (2015): 163-179.

Deniz, Şefaattin. “Teşvikiye Camisi'nin İnşaatı (1853-1854), İstanbul: Türk Dünyası Araştırmaları. 221. Sayı, Nisan (2016): 163-189.

Deniz, Şefaattin. Çırağan/Küçük Mecidiye Camii ve 2012-2015 Restorasyon Çalışmaları. İstanbul: Vakıflar Genel Müdürlüğü Yayınları -126/ Oksijen Matbaacılık, 2017.

Dırağ, Havanen. 1831-1900 Yılları Arasındaki İstanbul Yangınları. Basılmamış Mezuniyet Tezi, İstanbul: İstanbul Üniversitesi İstanbul, 1977. 
Diyanet İslam Ansiklopedisi. Ali Akyıldız. 24. cilt. İstanbul: İslam Araştırmaları Merkezi 2001: 212-215.

Diyanet İslam Ansiklopedisi. Ara Altun. 7. cilt., İstanbul: İslam Araştırmaları Merkezi 1993: 539-540.

Diyanet İslam Ansiklopedisi. Cengiz Kallek. 33. cilt. İstanbul: İslam Araştırmaları Merkezi 2007: 338-339.

Diyanet İslam Ansiklopedisi. İzmet Özmel. 25. cilt. İstanbul: İslam Araştırmaları Merkezi 2002: 107-108.

Diyanet İslam Ansiklopedisi. Mehmet İpşirli. 7. cilt. İstanbul: İslam Araştırmaları Merkezi 1993: 546-548.

Diyanet İslam Ansiklopedisi. Reşat Öngören. 16. cilt. İstanbul: İslam Araştırmaları Merkezi 1997: 310-311.

Diyanet İslam Ansiklopedisi. Salim Aydüz. 31. cilt. İstanbul: İslam Araştırmaları Merkezi 2006: 413-415.

Diyanet İslam Ansiklopedisi. Tahsin Yazıcı - Mehmet İpşirli. 12. cilt. İstanbul: İslam Araştırmaları Merkezi 1995: 408-409.

Donald Quataert. “19. Yüzyıla Genel Bakış Islahat Devri 1812-1914.” Osmanlı İmparatorluğu'nun Ekonomik ve Sosyal Tarihi, II Editör: Halil İnalcık, Donald Quataert, İstanbul: Eren Yayıncilık, 2006.

Evliya Çelebi. Evliya Çelebi Seyahatnamesi Topkapı Sarayı Bağdat 304 Yazmasının Transkripsiyonu-Dizini. Haz. Orhan Şaik Gökyay 1. Kitap, İstanbul: Yapı Kredi Yayınları, 1996.

Eyice, Semavi. İstanbul Minareleri I. İstanbul: Berksoy Matbaası, 1962.

Kömürciyan, Eremya Çelebi. İstanbul Tarihi XVIII. Asırda İstanbul. İstanbul: Eren Yayınları, 1988.

Kumbaracılar, İzzet. İstanbul Sebilleri. Ankara: Kültür Bakanlığı, 1938.

Necipoğlu, Gülrü. Sinan Çă̆l: Osmanlı İmparatorluğu'nda Mimari Kültür. Sinan'ın eserlerinin mimari çizimleri ile fotoğrafları Arben N. Arapi, Reha Güven; Çev. Gül Çağalı Güven. İstanbul: İstanbul Bilgi Üniversitesi, 2013.

Pakalın, Mehmet Zeki. Osmanlı Tarih Deyimleri ve Terimleri Sözlüğ̈̈. 1. cilt., İstanbul: Millî Eğitim Basımevi, 1983.

Pakalın, Mehmet Zeki. Osmanlı Tarih Deyimleri ve Terimleri Sözlüğ̈̈̈. 2. cilt., İstanbul: Millî Eğitim Basımevi, 1983. 
Pamuk, Şevket. Osmanlı İmparatorluğu'nda Paranın Tarihi. İstanbul: Tarih Vakfı Yurt Yayınları, 1999.

Peçevi İbrahim Efendi. Peçevi Tarihi. 1. cilt. Haz. Bekir Sıtkı Baykal, Ankara: Kültür Bakanlığı, 1981.

Ressam Hüsni. Bedâyi'-i Âsâr-ı Osmâniye. İstanbul: Matbaa-i Harbiyye, 1335.

Sahhaflar Şeyhi-Zâde Seyyid Mehmed Es'ad Efendi, Vak'a-Nüvîs Es'ad Efendi Tarihi (Bâhir Efendi'nin Zeyl ve İlâveleriyle) 1237-1241/1821-1826, Haz. Ziya Y1lmazer, İstanbul: Osmanlı Araştırmaları Vakfi, 2000.

Şem'dânî-zâde Findıklılı Süleyman Efendi Tarihi. Müri't-tevârih II.B., Haz. M. Münir Aktepe. İstanbul: İstanbul Edebiyat Fakültesi Matbaası, 1980.

Sezgin, Haluk. Türk İslam Ülkeleri Mimarisine Toplu Bakış. İstanbul: Mimar Sinan Üniversitesi Yayınları, 1979.

Süleymaniye Vakfiyesi. Haz. Kemal Edip Kürkçüoğlu. Ankara: Vakıflar Umum Müdürlüguü Neşriyatı, 1962.

Turan, Şerafettin. Kanunî’nin Oğlu Şehzade Bayezid Vakâsı. Ankara: Türk Tarih Kurumu, 1961.

Türker, Ebru. Cihangir Camisi Mimarlık Tarihi. Basılmamış Yüksek Lisans Tezi, İstanbul: İstanbul Teknik Üniversitesi, 2015.

Uzunçarşı11, İsmail Hakkı. Osmanlı Tarihi, 2. cilt. Ankara: Türk Tarih Kurumu, 1961.

Yılmaz, Yasin. Kanûnı̂ Vakfiyesi Süleymaniye Külliyesi. Ankara: Vakıflar Genel Müdürlüŭü, 2008. 